\title{
NUTRITION AWARENESS AND MEAT CONSUMPTION OF COLLEGE STUDENTS
}

\author{
By \\ KELLIE R. BRYANT \\ Bachelor of Science \\ oklahoma state University \\ stillwater, oklahoma
}

1992

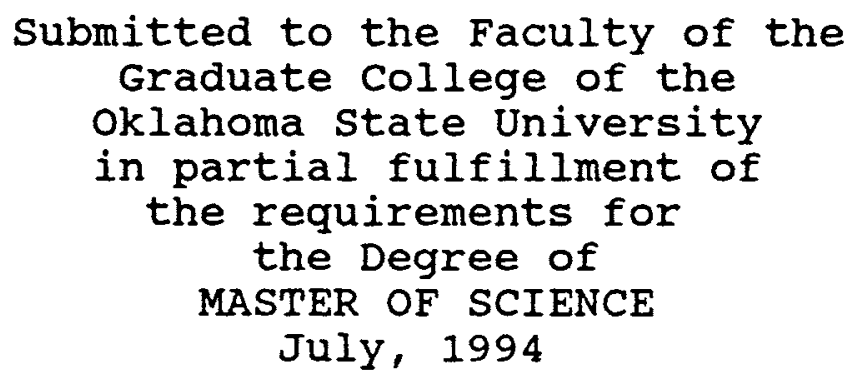




\section{OKLAHOMA STATE UNIVERSITY}

NUTRITION AWARENESS AND MEAT CONSUMPTION

OF COLLEGE STUDENTS

Thesis Approved:

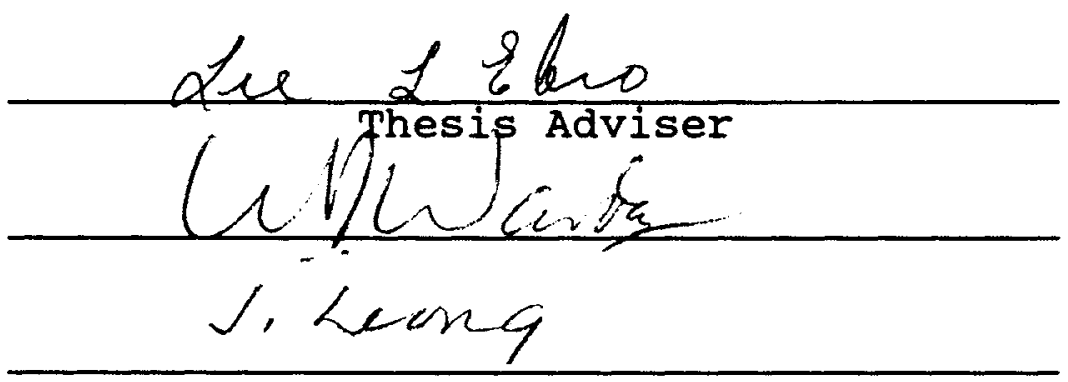

Thomas C. Colline 


\section{ACKNOWLEDGMENTS}

I would like to express my sincere appreciation to my major advisor, Dr. Lea Ebro, for her encouragement and assistance throughout my academic career. As my mentor, she has taught me many invaluable lessons I will keep with me throughout my professional career. My thanks also goes to my committee members, Dr. William Warde and Dr. Jerrold Leong, for their input and guidance during my research. A special thanks goes to the Department of Residential Iife, Dr. Robert Huss and Dr. William Ryan for providing names of research subjects and partially funding the data collection. To Dad, Mom, Sarah, Trinity, Kimberly and Chris, thank you for all of the financial support, love and friendship to help me accomplish my goal. To my family, I dedicate my thesis. 
TABLE OF CONTENTS

Chapter

Page

I. INTRODUCTION . . . . . . . . . . . . . . . 1

Purpose and objectives of the Study . . . . 2

Hypotheses . . . . . . . . . . 2

Assumptions and Limitation . . . . . . 3

Definition of Terms . . . . . . . . . 3

II. REVIEW OF LITERATURE . . . . . . . . . . . . . 6

Historical Review of Food Patterns . . . . 6

Contribution to Diet . . . . . . . . 8

Economic and Ecological Value. . . . . 10

Nationwide Consumption Patterns . . . . . 11

Data from National Food Review . . . 11

USDA, Economic Research Service, Commodity Economics Division

Research . . . . . . . . . . 12

Data from Meat Consumption Trends

and Patterns.......... . . 13

College Student Consumption Data . . . . 13

The Food Guide Pyramid . . . . . . . 16

Health Issues . . . . . . . . . . 17

Summary . . . . . . . . . . . . 19

III. METHODOLOGY . . . . . . . . . . . 20

Research Design . . . . . . . . . 20

Population and Sample... . . . . . . 21

Data Collection ....... . . . . . 21

Instrumentation . . . . . . . . . . 21

Procedures . . . . . . . . . . . . 22

Data Analysis... . . . . . . . . . 22

IV. RESULTS AND DISCUSSION . . . . . . . . . . . . 24

Characteristics of Survey Respondents . . . 24

Age, Sex, and Race... . . . . . . 24

Education, College, and Meal Plan . . 25

Responses to Descriptive Questions . . . . 25

Breakfast, Lunch, and Dinner

Per Week . . . . . . . . . . 25

Choice and Selection of Meat. . . . 27

cooking and Preparation Method . . . 27 
Knowledge of USDA Food Guide Pyramid . 27 Nutrition Awareness of College Students . . 30 Meat Consumption . . . . . . . . . . 33

Statistical Analyses . . . . . . . . . 38

The Instrument . . . . . . . . . . 38

Testing of the Hypothesis one . . . 38

Nutrition Awareness: Foods/Nutrients to

Limit by Gender and Education Level . . 40

Nutrition Awareness: Concerns and

Importance by Gender, Education Level and College . . . . . . . . . . . . . 42

Testing of the Hypothesis Two . . . . 45

Nutrition Awareness: Consumption Patterns

by Gender and College . . . . . . . . . 47

Meat Consumption by Gender, Race, Education Level and College . . . . . .

Testing of the Hypothesis Three . . . 51

Meat Consumption by Limit: Sodium, Sugar, Cholesterol and Fat . . . . .

Meat Consumption by Limit: Highly

Processed Foods, Alcoholic Beverages, Carbonated Beverages and Snack Foods

Meat Consumption by Importance or Concern for Food Labels with Nutrient Information and Diet, Health and Nutrition

Consumption of Meat by Importance or Concern for Nutritional Value, Caloric Content and Vitamin and Mineral Content.

Consumption of Meat by Importance or Concern for Appearance and condition and Taste and Flavor . . . . . . . .

Consumption of Meat by Importance or Concern for Convenience and Price... .

Meat Consumption by Importance or Concern for Variety, and Packaging . . . . . .

Meat Consumption by Importance or Concern for Additives and Preservatives, Irradiation, Residue, Hormones, and Bioengineered Foods ...... . . .

Meat Consumption by Recommended Servings

of Meat . . . . . . . . . . . . . .

V. SUMMARY AND RECOMMENDATIONS . . . . . . . . . . . 84

Recommendations . . . . . . . . . . 85

Implications . . . . . . . . . . . 86 
APPENDIXES • . . . . . . . . . . . . . . . . . . 91

APPENDIX A - COVER LETTER AND QUESTIONNAIRE - 92

APPENDIX B - FOOD GUIDE PYRAMID . . . . . 100

APPENDIX C - RECOMMENDED DIETARY GUIDELINES - 102

APPENDIX D - CHI-SQUARE FREQUENCY ANALYSIS

TABLES FOR THOSE ASSOCIATIONS

WHICH WERE SIGNIFICANT . . . . . 104

APPENDIX E - INSTITUTIONAL REVIEW BOARD

APPROVAL FORM . . . . . . . . . 117 


\section{LIST OF TABLES}

Table

Page

1. Demographic Variables of Respondents . . . . 26

2. Responses to Descriptive Questions . . . . . 29

3. USDA Food Guide Pyramid . . . . . . . . . 29

4. Meat Consumption by Respondents During the Past Week or Month . . . . . . . . . 34

5. Meat Consumption Groups for statistical Analysis . . . . . . . . . . . . . 39

6. Chi-Square Determinations Indicating Associations Between Nutrition Awareness: Foods/Nutrients to Limit and selected Personal Characteristics . . . . . . . .

7. Chi-Square Determinations Indicating Associations Between Nutrition Awareness: Concerns and Importance and Selected Personal Characteristics . . . . . . . .

8. Chi-Square Determinations Indicating Associations Between Nutrition Awareness: Consumption Patterns and Selected Personal Characteristics . . . . . . .

9. T-Test Determination of Meat by Gender of Respondents . . . . . . . . . . . . . .

10. Analysis of Variance (ANOVA) Results for Shrimp Consumption and Race . . . . . . .

11. Duncan's Multiple Range Test for Race and Shrimp Consumption . . . . . . . . .

12. Analysis of Variance (ANOVA) Results for Education and Cured Beef Consumption . . .

13. Duncan's Multiple Range Test for Education and Cubed Beef Consumption . . . . . . . 
14. Analysis of Variance (ANOVA) Results for other Beef Consumption and College . . . . .

15. Duncan's Multiple Range Test for other Beef Consumption and college . . . . . .

16. T-Test Determination on Consumption of Meat by Nutrition Awareness: Limit Sodium . . .

17. T-Test Determination on Consumption of Meat by Nutrition Awareness: Limit Sugar . . .

18. T-Test Determination on Consumption of Meat by Nutrition Awareness: Limit Cholesterol.

19. T-Test Determination on Consumption of Meat by Nutrition Awareness: Limit Fat... . .

20. T-Test Determination on Consumption of Meat by Nutrition Awareness: Limit Highly Processed Food . . . . . . . . . . . .

21. T-Test Determination on Consumption of Meat by Nutrition Awareness: Limit Alcoholic Beverages . . . . . . . . . . . . . . .

22. T-Test Determination on Consumption of Meat by Nutrition Awareness: Limit Carbonated Beverages . . . . . . . . . . . . . .

23. T-Test Determination on Consumption of Meat by Nutrition Awareness: Limit Snack Foods.

24. T-Test Determination on Consumption of Meat by Nutrition Awareness: Importance or Concern for Food Labels with Nutrient Information . . . . . . . . . . . .

25. T-Test Determination on Consumption of Meat by Nutrition Awareness: Importance or Concern for Diet, Health, and Nutrition . .

26. T-Test Determination on Consumption of Meat by Nutrition Awareness: Importance or Concern for Nutritional Value . . . . . .

27. T-Test Determination on Consumption of Meat by Nutrition Awareness: Importance or Concern for Caloric Content 
28. T-Test Determination on Consumption of Meat by Nutrition Awareness: Importance or Concern for Vitamin and Mineral content . .

29. T-Test Determination on Consumption of Meat by Nutrition Awareness: Importance or Concern for Appearance and Condition . . .

30. T-Test Determination on Consumption of Meat by Nutrition Awareness: Importance or Concern for Taste and Flavor . . . . . . .

31. T-Test Determination on Consumption of Meat by Nutrition Awareness: Importance or Concern for Convenience . . . . . . . . .

32. T-Test Determination on Consumption of Meat by Nutrition Awareness: Importance or Concern for Price . . . . . . . . . . .

33. T-Test Determination on Consumption of Meat by Nutrition Awareness: Importance or Concern for Variety . . . . . . . . . . .

34. T-Test Determination on Consumption of Meat by Nutrition Awareness: Importance or Concern for Packaging . . . . . . . . . .

35. T-Test Determination on Consumption of Meat by Nutrition Awareness: Importance or Concern for Additives and Preservatives . .

36. T-Test Determination on Consumption of Meat by Nutrition Awareness: Importance or Concern for Preservation by Irradiation . .

37. T-Test Determination on Consumption of Meat by Nutrition Awareness: Importance or Concern for Residue . . . . . . . . .

38. T-Test Determination on Consumption of Meat by Nutrition Awareness: Importance or Concern for Hormones in Meat . . . . . . .

39. T-Test Determination on Consumption of Meat by Nutrition Awareness: Importance or Concern for Bioengineered Foods . . . . . 
40. Analysis of Variance (ANOVA) Results for Cubed Beef Consumption and Nutrition Awareness: Recommended Servings of Meat . .

41. Duncan's Multiple Range Test for Nutrition Awareness: Recommended Servings of Meat and Cubed Beef Consumption . . . . . . .

42. Analysis of Variance (ANOVA) Results for Beef strip Consumption and Nutrition Awareness: Recommended Servings of Meat . .

43. Duncan's Multiple Range Test for Nutrition Awareness: Recommended Servings of Meat and Beef strip Consumption . . . . . . .

44. Analysis of Variance (ANOVA) Results for other Beef Consumption and Nutrition Awareness: Recommended Servings of Meat .

45. Duncan's Multiple Range Test for Nutrition Awareness: Recommended Servings of Meat and Other Beef Consumption . . . . . . .

46. Analysis of Variance (ANOVA) Results for Pork Consumption and Nutrition Awareness: Recommended Servings of Meat . . . . . .

47. Duncan's Multiple Range Test for Nutrition Awareness: Recommended Servings of Meat and Pork Consumption . . . . . . . . . .

48. Analysis of Variance (ANOVA) Results for Total Pork Consumption and Nutrition Awareness: Recommended Servings of Meat .

49. Duncan's Multiple Range Test for Nutrition Awareness: Recommended Servings of Meat and Total Pork Consumption . . . . . . . .

50. Analysis of Variance (ANOVA) Results for Fish Consumption and Nutrition Awareness: Recommended Servings of Meat . . . . . . .

51. Duncan's Multiple Range Test for Nutrition Awareness: Recommended Servings of Meat and Fish Consumption . . . . . . . . . .

52. Analysis of Variance (ANOVA) Results for Seafood Consumption and Nutrition Awareness: Recommended Servings of Meat . 
53. Duncan's Multiple Range Test for Nutrition Awareness: Recommended Servings of Meat and Seafood Consumption . . . . . . . .

54. Analysis of Variance (ANOVA) Results for Total seafood Consumption and Nutrition Awareness: Recommended Servings of Meat .

55. Duncan's Multiple Range Test for Nutrition Awareness: Recommended Servings of Meat and Total Seafood Consumption . . . . . 


\section{LIST OF FIGURES}

Figure

Page

1. Per Capita Use of Meats, Poultry, and Fish Boneless and trimmed equivalent, 1970, 1980, and 1991 . . . . . . . . . . . . . . . . . . .

2. Percent of students Consuming Breakfast, Lunch, and Dinner Per Week . . . . . . . . . . . . 28

3. Percent of students Limiting Intake of Food Substances Which Have Had Health Implications • 31

4. Percent of Students Indicating Importance or Concern of Selected Nutrition Awareness Variables 
CHAPTER I

\section{INTRODUCTION}

In today's health conscious society, nutrition plays a very vital role. Consumers have become very conscientious when making food choices and selections. Words such as fat and cholesterol have become common household topics. This new wave of health conscious consumers has shown a decline in meat consumption and a misconception that meat is unhealthy. Many consumers do not realize that meat if eaten in moderation is an important component to the human diet. The Food and Nutrition Board, National Academy of Science has stated that meat, poultry, and fish provide essential nutrients (Thomas, 1991). Meat is a valuable resource of high biological value protein, B-12, niacin, riboflavin, zinc, and iron (Chou, 1983). Khan and Lipke (1982) reported that college students are inclined to develop poor eating habits. This group may have a tendency to follow fad or low calorie diets, skip meals, and avoid nutritious foods (Hernon, Skinner, Andrews, and Penfield, 1986). Often, damaging effects of poor dietary behavior can result in health problems, which may surface now or later in life (Marrale, Shipman, and Rhodes, 1986). 
Nutrition experts need to assess the amount of meat consumed and determine the nutritional awareness of this particular group. The assessment will enable educators to target eating patterns and develop nutrition related tools to promote good dietary habits and alleviate misconceptions about meat.

Purpose and objectives of the study

The purpose of this study is to determine the types and amounts of meat consumed by oklahoma state University resident hall students (to be referred to hereafter as college students) and to determine if there is an association between college students' nutrition awareness, and consumption patterns.

The objectives of the study were to:

1. Identify the type and amount of meat consumed by college students.

2. Relate selected personal variables with nutrition awareness: foods to limit, concerns and importance, and consumption patterns.

3. Determine the impact of nutrition awareness among college students toward consumption of meat.

\section{Hypotheses}

The following hypotheses were examined:

1. There will be no significant association between 
the college students' personal variables and their nutrition awareness: foods to limit, concerns and importance, and consumption patterns.

2. There will be no significant association between meat consumption of college students and the selected personal variables: gender, race, age, education level, and college.

3. There will be no significant association between meat consumption patterns of college students and their nutrition awareness: foods to limit, concerns and importance, and consumption patterns.

\section{Assumptions and Limitations}

The assumptions of this research were:

1. The students honestly answered the questionnaire to the best of their abilities.

2. The students were knowledgeable enough about their intake of meat to actually answer the questionnaires.

one limitation of this research was that only a random sample of students $(n=962$ out of 3300$)$ living in the resident halls at oklahoma state University in the spring semester of 1994 were surveyed. Another limitation of the study was the fact that the students' choices of meats were controlled by the menu cycle in the residence halls foodservive operations. Besides having a meal plan, students also had access to fast foods and a health club in 
the residence halls. Those with less than a 20 meal plan also dined off campus.

\section{Definition of Terms}

For the purpose of this study the following terms were defined so that the researcher's intent was understood specifically.

Additives - A preservative added to food (Guralnik, 1979).

Awareness - knowing or realizing being conscious or informed (Guralnik, 1979).

Bioavailability - Descriptive term for the extent of digestion and absorption of a nutrient; therefore the amount actually available for cell utilization (Claudio \& Lagua, 1991).

Bioengineered Foods - Foods that have been genetically altered.

Cholesterol - a fatlike compound with a complex ring structure; the chief sterol in the body found in all tissues, especially the brain, nerves, adrenal cortex, and liver. It is synthesized in the liver and other organs and is found only in animal products (Claudio \& Lagua, 1991). Consumption - ingestion of food items.

High Biological Value Protein - proteins which have a high merit for meeting the body's need for amino acids. Hormones - substance injected into animals to promote growth, development and to decrease the amount of fat. 
Irradiation of Food - pertains to ionizing radiation that destroys various microorganisms (Freeland-Graves \& Peckham, 1987).

Meat - ingestion of beef, lamb, pork, veal, chicken, turkey, fish, seafood, and wild game.

Misconception - to interpret incorrectly (Guralnik, 1979) •

Moderation - avoidance of excesses or extremes (Guralnik, 1979).

Poultry - Chicken and turkey; wild fowl is considered miscellaneous.

Preservatives - A substance added to food to keep it from spoiling (Guralnik, 1979).

Processed Foods - foods such as bologna, sausage and franks.

Red Meat - Beef, lamb, pork and veal.

Residue - The matter remaining at the end of a process, as after evaporation, combustion, filtration, et cetera (Guralnik, 1979) .

Variety - A number of different kinds; an assortment (Guralnik, 1979). 


\section{CHAPTER II}

\section{INTRODUCTION}

Meat consumption has played a vital role in the diet of man as far back as history records exist. Although it has always played a part in the diet, the consumption of meat has been criticized even in biblical times (Environmental Nutrition, 1979). Even though the consumption of meat has received much criticism, most Americans include some type of meat in their diet in spite of the many health controversies. This chapter will trace the development of attitudes towards, and consumption patterns of meat through an examination of historical development, diet contributions, consumption patterns, economic value, and health issues.

\section{Historical Review of Food Patterns}

Throughout the six million years of human existence, people have found means of producing adequate, palatable, ecologically adaptive, and ideologically acceptable diets within a vast range of environmental contexts and cultural patterns (Jerome, Kandel \& Pelto, 1980). Over these years with increased population and technology, food resources have greatly expanded. 
Reconstruction of prehistoric human diets from archaeological remains is based upon a record that is of necessity incomplete (Jerome et al., 1980). In spite of these problems, generalizations on dietary trends over a time can be made.

The nutrition cultural revolution of food patterns begins with the hunter-gatherer population. Hunting and gathering is an omnivorous compromise between the more nutritionally-efficient hunting of animals with proper amino acid rations and the more ecologically-efficient gathering of vegetal materials at low trophic levels (Jerome et al., 1980). These groups utilized widely different diet patterns depending upon region and resource.

Some groups relied primarily on animal flesh while others consumed vegetal materials depending on what was the most plentiful in the region-specific environment. Depending upon region and resource, hunting groups must have utilized widely different diet patterns, and adaptive responses must have varied widely (Jerome et al., 1980).

Growing populations made it more difficult for the hunter-gatherer groups to obtain enough food. Scarce amounts of food lead to the emergence of agriculturist groups.

The agriculturists learned to cultivate plants and domesticate animals, however, the earliest agriculturists faced feast and famine situations and seasonal resource changes. From these situations, humans learned to store 
food.

Food is thus available to most humans, permitting the development of food habits, such as the setting of mealtimes (Kitler \& sucher, 1989). In addition, humans cook food, which greatly expanded the number and variety of edible substances available; choice of what to eat followed (Kitler \& Sucher, 1989).

\section{Contribution to Diet}

Protein consumption has declined since the beginning of the 20 th century but remains adequate to meet the recommended dietary allowances for all groups. Animal protein accounts for two-thirds of the total protein supply (Chou, 1983).

The animal protein consumed by most Americans is beef. Red meat consumption peaked in 1976 and dropped to an alltime low in 1982 (Borchelt, 1988). It has however, shown a steady increase since then. The decline is attributed to many consumer beliefs that beef is high in fat, calories, and cholesterol. Therefore, with these beliefs, beef has not fit into the consumer attitudes and lifestyles of the present decade which has favored foods that are "lighter," "lower in calories," and "good for you." Beef can and should fit, however, into such diets (Adolf, 1987). The beef industry has responded by physically removing much of the adipose tissue from retail products and by initiating attempts to produce-genetically and environmentally-cattle 
with more muscle, less external fat, and less seam fat, without sacrificing the quality dependent on the amount of marbling present (Sweeten, Cross, Smith, Savel, \& Smith 1990). The United States Department of Agriculture (USDA) standards of grading beef require high grading for a good relationship between marbling (intramuscular fat) and eating qualities. A poorer grading is given to beef carcass with advancing physiological maturity that usually affects taste appeal (Breidenstein, 1987). Therefore, as cattle age, marbling increases which is required for a given quality grade. Modern beef production techniques have resulted in cattle reaching market weight at a much younger age than ever before. USDA marbling requirements for choice grade were reduced in 1950 from a minimum slightly abundant amount to a minimum small amount (Breidenstein, 1987).

Beef producer's have altered breeding and feeding practices to increase muscle mass and decrease body fatness. Thus, today's cattle have at least six percent less adipose tissue than their counterparts of the 1920's (Sweeten et al., 1990)

According to USDA, a three ounce serving of beef contains only 76 milligrams of cholesterol which is as much as three ounces of roast chicken with the skin removed (Adolf, 1987). Saturated fat is another issue which many Americans are expressing concern. Only 48 percent of the fat in beef is saturated; the remaining 52 percent is 
monounsaturated and polyunsaturated (Adolf, 1987). This can easily be translated into everyday consumption. The American Heart Association recommends a daily diet containing a maximum of seven ounces cooked lean meat and 300 milligrams of cholesterol per day (American Meat, 1985). Red meat falls within these limits by a three ounce serving of meat containing 76 milligrams of cholesterol and 8.7 grams of fat in which less than half is saturated. Red meat is an excellent source of dietary iron. Three ounces of red meat provides three milligrams of iron. Not only is it an excellent source of iron, but also it is present as heme iron which is more readily absorbed by the body than iron found in other foods (Adolf, 1987). Iron is very important for women because it is one of their most common deficiencies. It should also be noted that meat is a good source of $\mathrm{zinc}$ and some 40 other nutrients. The bioavailability of these nutrients is high, hence they are readily available to body tissues.

\section{Economic and Ecological Value}

In terms of economic efficiency, animals are beneficial because they are able to consume foods unfit for humans, filter out toxic materials and produce a palatable product (Hopkins \& Thomas, 1984). This is also an asset for our ecological system.

Cattle-raising contributes to the environment because 
beef cattle operations require little fossil fuel energy and can be compatible with wildlife production, water resource conservation and sound environmental management (Hopkins \& Thomas, 1984). This must be well understood by the rancher, because many times, land which cannot raise any other food may easily be pastured for animal production.

\section{Nationwide Consumption Patterns}

Statistics show that consumption patterns for meat have changed considerably over the last few decades. The most striking feature is the steady increase in poultry consumption, which has doubled in the last 20 years (Moschini \& Meilke, 1989). This can be explained partly because of the significant gain in poultry productivity and the resulting lower retained prices for poultry.

\section{Data from National Food Review}

Per capita consumption of meat can be divided into many categories. The most popular are beef, pork, fish, and chicken. In the 1960's beef consumption averaged 64.2 pounds per person; pork, 60.3 pounds; fish, 10.3 pounds; and chicken 27.8 pounds. The 1970's showed that per capita consumption averaged 84.0 pounds for beef; 62.3 pounds for pork, 11.8 pounds for fish, and 40.4 pounds for chicken. In 1976, beef reached historical highs of nearly 26 billion pounds nationally and 94.4 pounds per person. The 1980's 
statistics revealed a downward shift in beef consumption and an increase in pork and chicken. These averages were 76.5 pounds for beef, 68.3 pounds for pork, and 51.7 pounds for chicken.

Examining these trends between 1973 and 1980 , red meat consumption rose about six pounds per capita. Beef consumption decreased approximately four pounds per capita, but the 11 pound increase in pork consumption more than offset the decline in beef and other red meat consumption (Craven \& Haider, 1989). Poultry consumption increased by about 11 pounds per person and fish consumption declined only slightly. This decline may be attributed to the fact that fish prices increased 84 percent. Beef prices were up 68 percent, pork increased 28 percent, and poultry prices were up 21 percent.

USDA, Economic Research Service, Commodity Economics Division Research

In 1991, American used an average of 112 pounds of red meat, 58 pounds of poultry, and 15 pounds of $f$ ish and shellfish per capita. Red meat accounted for 61 percent of the total meat supply in 1991, compared with 70 percent in 1980 and 74 percent in 1970. By 1991, chicken and turkey accounted for 31 percent of the total meat used, up from 23 percent in 1980 and 19 percent in 1970. Fish and shellfish 
accounted for 8 percent of total meat used in 1971 and 7 percent in 1980 and 1970. In 1991, Americans used 21 pounds less red meat, 24 pounds more fish and shellfish per capita than in 1970 (Figure 1).

\section{Data from Meat Consumption Trends}

\section{and Patterns}

Relative to the size of population, the Northeast and West constitute the two largest markets for meat for household consumption, and the South on the same basis, the smallest market. In the Northeast, about three times as much of each kind of meat is bought than is produced. In the South, more than half of its demand for pork is bought outside of the region. There is no comprehensive information on meat consumption outside private homes, however, it is known that about 18 percent of the food sold to U. S. civilians is handled by eating places (Meat Consumption Trends, 1981).

\section{College Student Data}

Research by Marrale, Shipman, and Rhodes, (1986) reported that 49 percent of respondents reported eating two meals per day; while 36 percent reported eating three meals per day. Less than 25 percent of the subjects achieved a rating of "good" on their diary of food intake.

In a study by Hertzler and Frary, (1980) 43 percent of 
Pounds per year

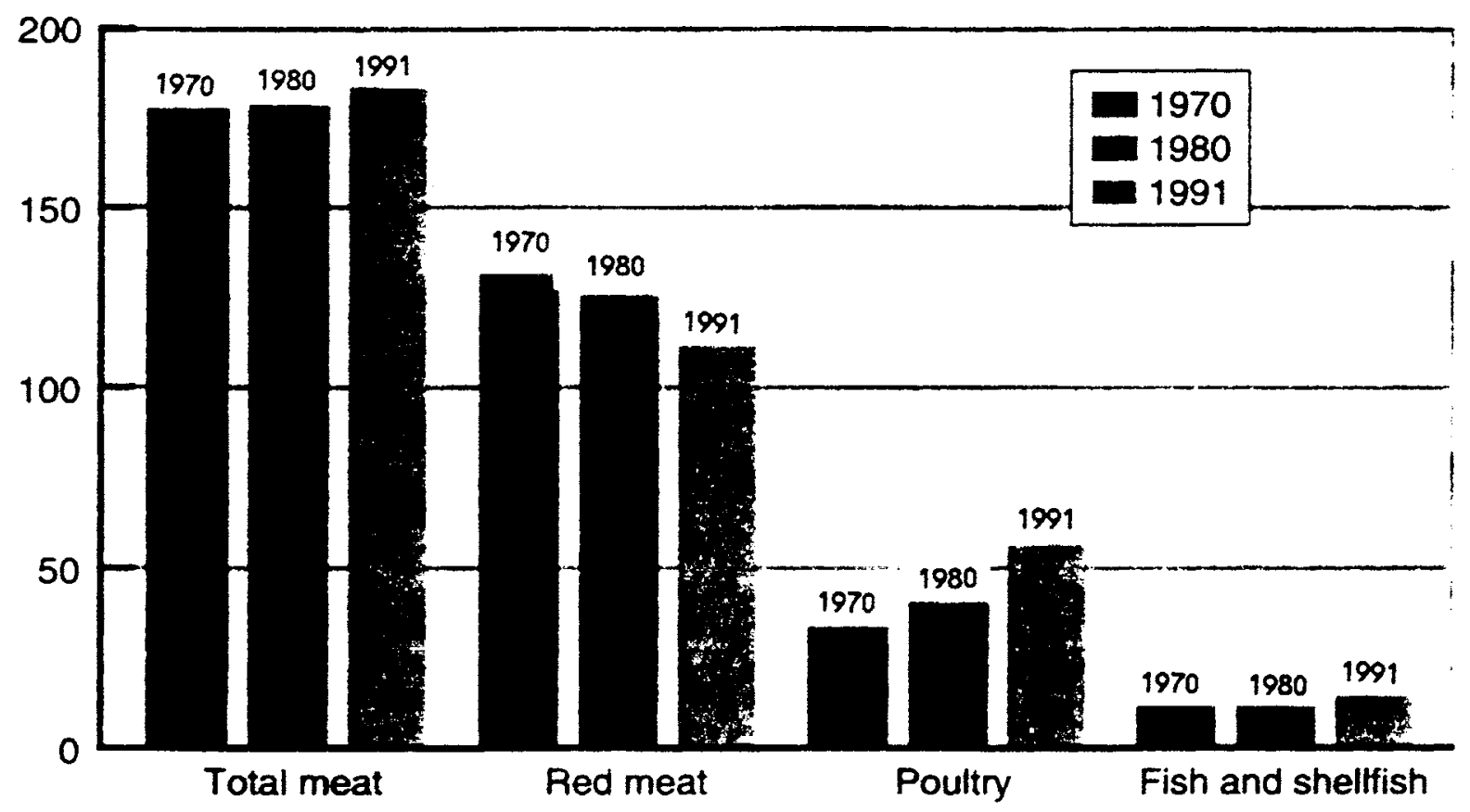

Source: U. S. Department of Agriculture, Economic Research Service, Commodity Economics Division.

Figure 1. Per Capita Use of Meats, Poultry, and Fish, Boneless and Trimmed Equivalent, 1970, 1980, and 1991 
the college students reported skipping breakfast half of the time. Similarly, Khan and Lipke in 1982; and Schank, Thomas, and Young, in 1987 reported that breakfast is the meal skipped most often by college students.

Cybel and Prather (1993) reported that foods such as tuna, lettuce, chicken, and most dairy products were viewed as being relatively more nutritious, lower in calories, better for you, and more unprocessed than items such as cola and chocolate. Another study (Chery, Sabry, woolcott, 1987) which compared nutrition knowledge and misconceptions of 1971 vs. 1984 suggested that students in 1984 had a higher level of nutrition knowledge than their counterparts of 1971. Many misconceptions still existed such as the belief that processing greatly reduces the nutritive value of foods.

Fast food items such as grilled cheese, sandwiches, hamburgers and steak sandwiches were selected more by men than women (Leux \& Manning, 1992). Men, also selected on the average, 1.5 hot entrees per person as compared to women who selected one hot entree per person. In the Lieux and Manning (1992) study, men chose foods with higher levels of nutrients in all categories except percent of calories from fat. Women selected a greater percentage of their energy from fat than did men. 
The Food Guide Pyramid

The Food Guide Pyramid was released by USDA and DHHS in 1992. The Pyramid was developed as a graphic presentation of the Dietary Guidelines for Americans (Appendix B) which were developed in 1980 and have been revised twice since then. The current Guidelines were issued in 1990. The Guidelines are:

- Eat a variety of foods,

- Maintain healthy weight,

- Choose a diet low in fat, saturated fat, and cholesterol,

- Choose a diet with plenty of vegetables, fruits, and grain products,

- Use sugars only in moderation,

- Use salt and sodium only in moderation, and

- If you drink alcoholic beverages, do so in moderation.

The research to develop the Food Guide Pyramid included five steps: establishment of nutritional goals, definition of food groups, Assignment of serving sizes, determination of nutrient profiles, and determination of the number of servings. Development of the food guide was presented to consumers in 1984 as part of a nutrition course developed by USDA in cooperation with the American National Red Cross.

Further research by USDA revealed a graphic representation of the Food Guide should be developed. The 
results of the graphic research led to the conclusion that the pyramid graphic with fat and added sugars symbols and a black background would be the most effective in communicating the key food guide concepts of variety, proportionality, and moderation.

The Food Guide Pyramid: A Guide to Daily Food Choices (Appendix B) is an outline of what to eat each day. The Pyramid demonstrates eating a variety of foods each day to get needed nutrients. Also, emphasis is placed on eating the right amount of calories to maintain a healthy weight. The meat group ( $2-3$ servings) is graphically represented as the Meat, Poultry, Fish, Dry Beans, Eggs, and Nuts Group.

\section{Health Issues}

Recent trends in health and fitness have focused increased attention on dietary behaviors in American society (Marrale, Shipman, \& Rhodes, 1986). Consumers are increasingly interested in health risks associated with meat consumption. Meat particularly beef has received much criticism from the public with concern to its contribution to cardiovascular disease and cancer.

obesity is a factor associated with increased risk for cardio vascular disease. It is true that excess weight can be derived from fats. Since the turn of the century, Americans have derived a higher proportion of fat from plant sources while the proportion of fat derived from animal 
sources has actually declined (Wyse, 1986). It is ironic, however, that the National Institute of Health's recommendations on coronary heart diseases and cancer ignore American's consumption of alcohol, sugar, and fat-laden snack foods (Wyse, 1986).

Research has proven that saturated fat may contribute to higher levels of cholesterol in the blood. This has had a negative effect on the meat industry because of the fact that meat does contain saturated fat. There seems to be a misconception from the general public that the way to lower cholesterol levels is to eliminate meat from the diet. The American Heart Association recommends that fat be reduced to 30 percent of total calories, and cholesterol to less than 300 milligrams per day. Other risk factors that are associated with cardiovascular disease are cigarette smoking, hypertension and diabetes. The consumption of meat has little effect on most of these factors.

In relation to cancer, a report from the National Cancer Institute clearly implicated dietary fats as a major area of concern and recommends that total dietary fats be reduced in cancer prevention programs (Wyse, 1986). The relationship between diet and cancer is still under much investigation. At the American Cancer Society workshop conference in 1982, it was the conclusion of the committee that there is no single dietary factor, including meat and fat, that can account for more than a small fraction of cancer in the United States (Pariza, 1984). 
The key toward a healthful diet is not the elimination of certain meat products but to eat meat in moderation as specified by the Recommended Dietary Guidelines. Over consumption of any type of food can lead to obesity which can lead to serious health problems. More attention needs to be emphasized on the nutritional consequences of alcohol, snack and "junk" foods. The information the media has portrayed about meat as a food which is high in fat and cholesterol has probably not fostered concepts and habits associated with good nutrition.

\section{Summary}

The impact meat consumption plays in our environment has been well documented. Meat is an important source of many nutrients needed for humans, provides ecological balance and is profitable for people in the meat industry. In summary, the consumption of meat within recommended amounts is beneficial to the lives of all human beings. 
CHAPTER III

METHODOLOGY

This study was designed to assess the nutrition awareness and meat consumption of college students living in the resident halls at oklahoma state University, and was approved by the Director of Residential Life and by the osU Institutional Review Board (Appendix E). This chapter includes the research design; population and sample; data collection which includes instrumentation and procedures; and data analysis.

\section{Research Design}

A descriptive status survey or assessment in the form of a mailed questionnaire was developed for this study. It was designed to measure the nutrition awareness of college students towards meat and their current selection criteria. These students will have been exposed through the media and literature information about health issues concerning meat consumption. The relationship between the variables is the focus of this study (Best, 1981).

The dependent variables in this study were the consumption of meat and nutrition awareness of college students. The independent variables were selected personal 
characteristics and nutrition awareness of Oklahoma state University students.

\section{Population and Sample}

The population in this study were all students registered at the Residential Life office in the spring semester of 1994. From this population, a random sample of 962 students were chosen to respond to the questionnaire. The questionnaires were distributed by Residential Life employees to the mail boxes of the selected students. All six resident halls were represented in this study.

\section{Data collection}

\section{Instrumentation}

The questionnaire was designed to provide the Department of Residential Life with information that could be potentially useful to the university foodservice in that the menu planners will have insight into the students' food preferences and choices. The survey was developed by the researcher adapting questions from surveys developed by Rebecca Plato, M.S., R.D. (1993), Joy Galloway, M.S., R.D. (1991), Andrea Ridgway, M.S., R. D. (1989) and other studies from the review of literature.

The instrument was divided into three parts: general information, nutrition awareness, and meat consumption questions. Part I included demographics and selected 
descriptive questions. Part II comprised questions concerning attitude, behavior and knowledge of meat consumption/selection. Part III was designed to measure actual consumption. These questions are identified in the results section of Chapter IV.

In order to check for readability, clarity, content, validity, format, and the amount of time necessary to complete the questionnaire, the research instrument was pre-tested with 12 students enrolled in a graduate foodservice management course. Modifications were made based on analysis of responses and suggestions made by the students, and the graduate committee.

\section{Procedures}

Those students randomly chosen to participate in the study were mailed the questionnaire and informed in writing of the purposes of the survey. Instructions were provided in the cover letter. They were assured of confidentiality, instructed to complete the survey, and to return it within one week to the front desk of their resident halls. As an incentive for participation, students were given a treat to be awarded at the front desk to those who completed and returned a survey.

Data Analysis

All questionnaires received within three weeks of the mailing were included in the data analysis. Of the 962 
surveys mailed to students, a total of 257 were returned, yielding a response rate of 27 percent. The data were coded and filed on a PC file and tabulated for analysis. The information was processed through a computer using the Statistical System Package (SAS, 1979). The researcher used frequencies and percentages generated by the computer to describe the personal characteristics of the respondents. Analysis of variance, student's t-test, Duncan's Multiple Range Tests, and Chi-squares were used to test the hypotheses in the study (Steel \& Torrie, 1980).

The six columns on the questionnaire which asked how often meat items were eaten were coded. For the coding, never was 0 , seldom was 0.5 , once per month was 1 , more than once per month was 2 , once per week was 4 , and more than once per week was 8 . These values were chosen to approximately represent the number of portions per month consumed by the respondents. The sums of the 106 items were totaled and converted to percent of meat consumed. 
CHAPTER IV

\section{RESULTS AND DISCUSSION}

The purpose of this study was to determine the nutrition awareness and meat consumption of oklahoma state University college students. Data were obtained using the research instrument described in Chapter III. The questionnaires were mailed to 962 resident hall students at Oklahoma state University during the spring semester, 1994 . The response rate was 27 percent $(\mathrm{N}=257)$. All returned survey instruments were usable for analysis.

\section{Characteristics of Survey Respondents}

Respondents were asked to provide general demographic data to determine personal characteristics. Questions asked included gender, race, age, education level, college, and meal plan purchased.

Age, Sex, and Race

of the 257 participants( $26.7 \%$ response rate), 41 percent $(\mathrm{N}=106)$ were male and 59 percent $(\mathrm{N}=151)$ were female. Over 80 percent of the respondents were white, $(\mathrm{N}=206,82 \%)$. The remaining were Black, Native American, Hispanic, and Asian. 
Nearly all of the respondents were between the ages of 17-22 $(\mathrm{N}=219,87 \%) \quad$ (Table 1$)$.

Education, College, and Meal plan

Most of the respondents indicated that they were freshmen $(\mathrm{N}=102,40 \%)$, while $26 \%$ were sophomore students. The remaining were juniors, seniors, graduate and special students. Eighty-four students were from the college of Arts and Sciences (33\%) followed by the Business (21\%) and Engineering (19\%) colleges. Eighty percent ( $N=145)$ of the students are on a 10 or 15 meal plan per week (Table 1 ).

Responses to Descriptive Questions

Participants were asked to answer special descriptive questions to provide data which could be compared to other studies. Information requested were number of times per week they ate breakfast, lunch and dinner; choice and selection of meat; and whether cooking or preparation method affected their selection of meat.

Breakfast, Lunch, and Dinner

Per Week

Nearly one third of the respondents reported not eating breakfast which supports the research by Khan and Lipke (1982) that breakfast is the meal skipped most often by college students. Thirty-five percent reported eating lunch five times per week and 27 percent reported eating lunch 
TABLE 1

DEMOGRAPHIC VARIABLES OF RESPONDENTS

$(\mathrm{N}=257)$

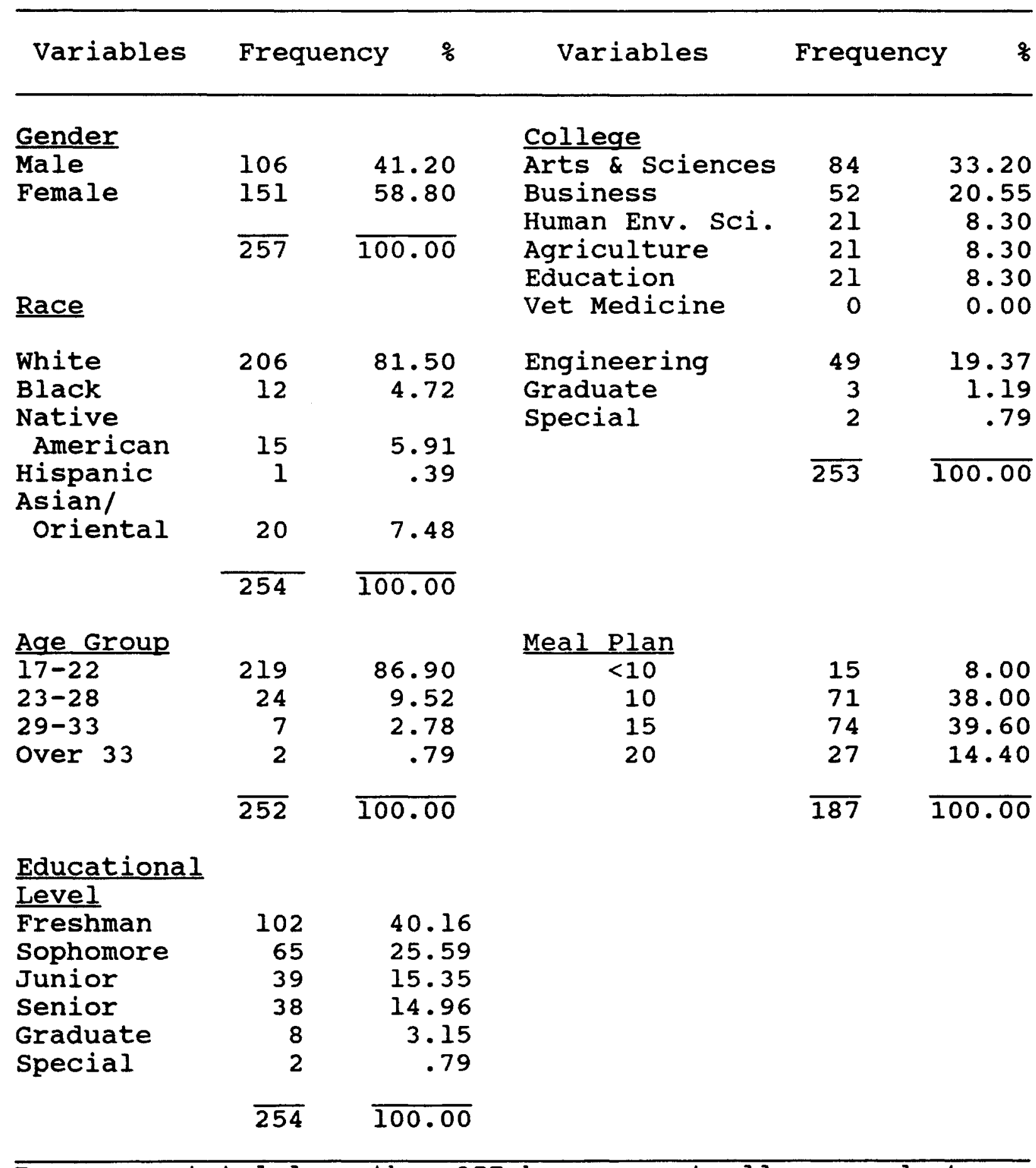

Responses total less than 257 because not all respondents answered all questions. 
seven times per week. Over 32 perdent of the respondents reported eating dinner seven times per week and 31 percent reported eating dinner five times a week. These data are similar to results reported by Plato (1993) who also studied oklahoma state University students. In the present study 21 percent did not eat breakfast, 32 percent ate lunch five times a week and 33 percent ate dinner five times per week.

\section{Choice and Selection of Meat}

Respondents were asked if the choice of meat was a factor in their selection of meat. Seventy-nine percent reported that choice did affect their selection of meat (Table 2).

\section{Cooking and Preparation Method}

The students were asked if cooking or preparation method was a factor in their choice of meat. Eighty-four percent answered yes, while the remaining 16 percent indicated that cooking or preparation of the meat was not a factor in their selection (Table 2).

\section{Knowledge of USDA Food Guide Pyramid}

students were asked their knowledge about the USDA Food Guide Pyramid. When asked how many servings of meat a day constitute a healthy diet, 75 percent $(\mathrm{N}=191)$ answered within the recommended two to three range. Seventeen percent answered 1 serving per day (Table 3 ). 


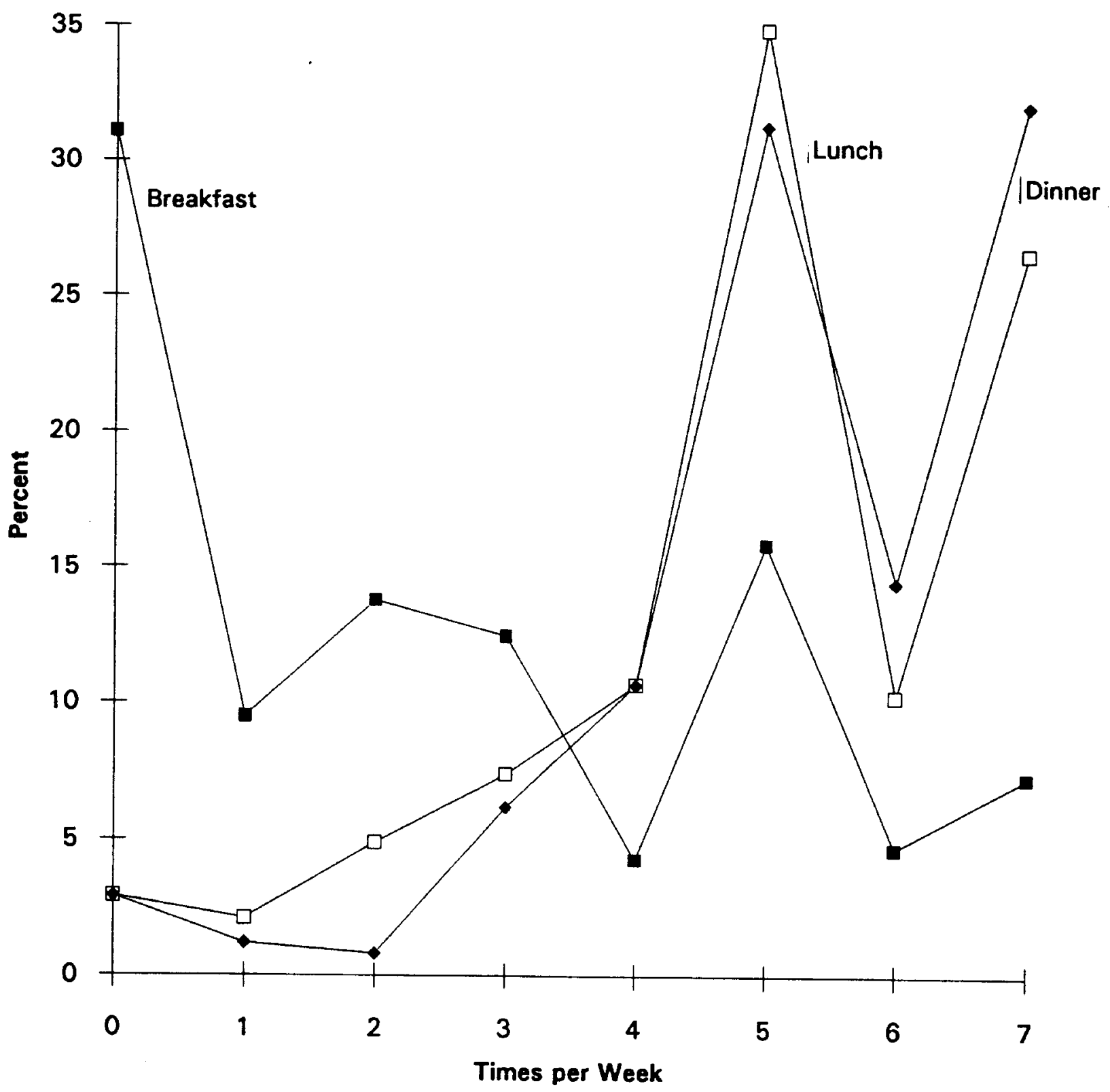

Figure 2. Percent of students Consuming Breakfast, Lunch and Dinner Per Week 
TABLE 2

RESPONSES TO DESCRIPTIVE QUESTIONS

\begin{tabular}{lcc}
\hline Variable & Frequency & Percent \\
\hline $\begin{array}{l}\text { Choice } \\
\text { Yes } \\
\text { No }\end{array}$ & 202 & 79.2 \\
Cooking/Preparation & 53 & 20.8 \\
$\quad$ Yes & 215 & 84.0 \\
No & 41 & 16.0 \\
$\begin{array}{l}\text { Responses total less than 257 because not all respondents } \\
\text { answered all questions. }\end{array}$
\end{tabular}

TABLE 3

USDA FOOD GUIDE PYRAMID

\begin{tabular}{crr}
\hline Variable & Frequency & Percent \\
\hline Meat & & \\
0 & 6 & 2.36 \\
1 & 42 & 16.54 \\
2 & 137 & 53.94 \\
3 & 54 & 21.26 \\
4 & 10 & 3.94 \\
5 or more & 5 & 1.97 \\
& 254 & 100.00 \\
\hline
\end{tabular}

Numbers may not total 100 due to rounding. 


\section{Nutrition Awareness of}

\section{College students}

In the 1990's, the general public was inundated with health issues by $\mathrm{TV}$, radio, newspapers, et cetera. Some of these sources are accurate, others misleading. Among many health concerns are sodium, fat, cholesterol, sugar and alcohol. In this study, students were asked if they tried to limit a variety of these contemporary health concerns. Forty-six percent indicated trying to limit sodium, 47 percent sugar, 66 percent cholesterol, 77 percent fat, 64 percent alcoholic beverages, 49 percent carbonated beverages and 66 percent snack foods (Figure 3). When asked questions about nutrition, respondents answered that they were concerned about food labels (66\%), diet, health and nutrition (78\%), nutritional value (71\%) and caloric content (50\%). Of the respondents, 94 percent stated that they were concerned with the appearance and condition of the food, 87 percent convenience and price, 90 percent variety, 52 percent vitamin/mineral content, and 65 percent with residue. In addition, 44 percent were concerned with additives/preservatives; 36 percent, with irradiation; 46 percent, with packaging; 41 percent, with hormones; and 40 percent, with bioengineered foods. Students were also asked if their consumption of food was related to their stress situation and 52 percent answered yes (Figure 4). 


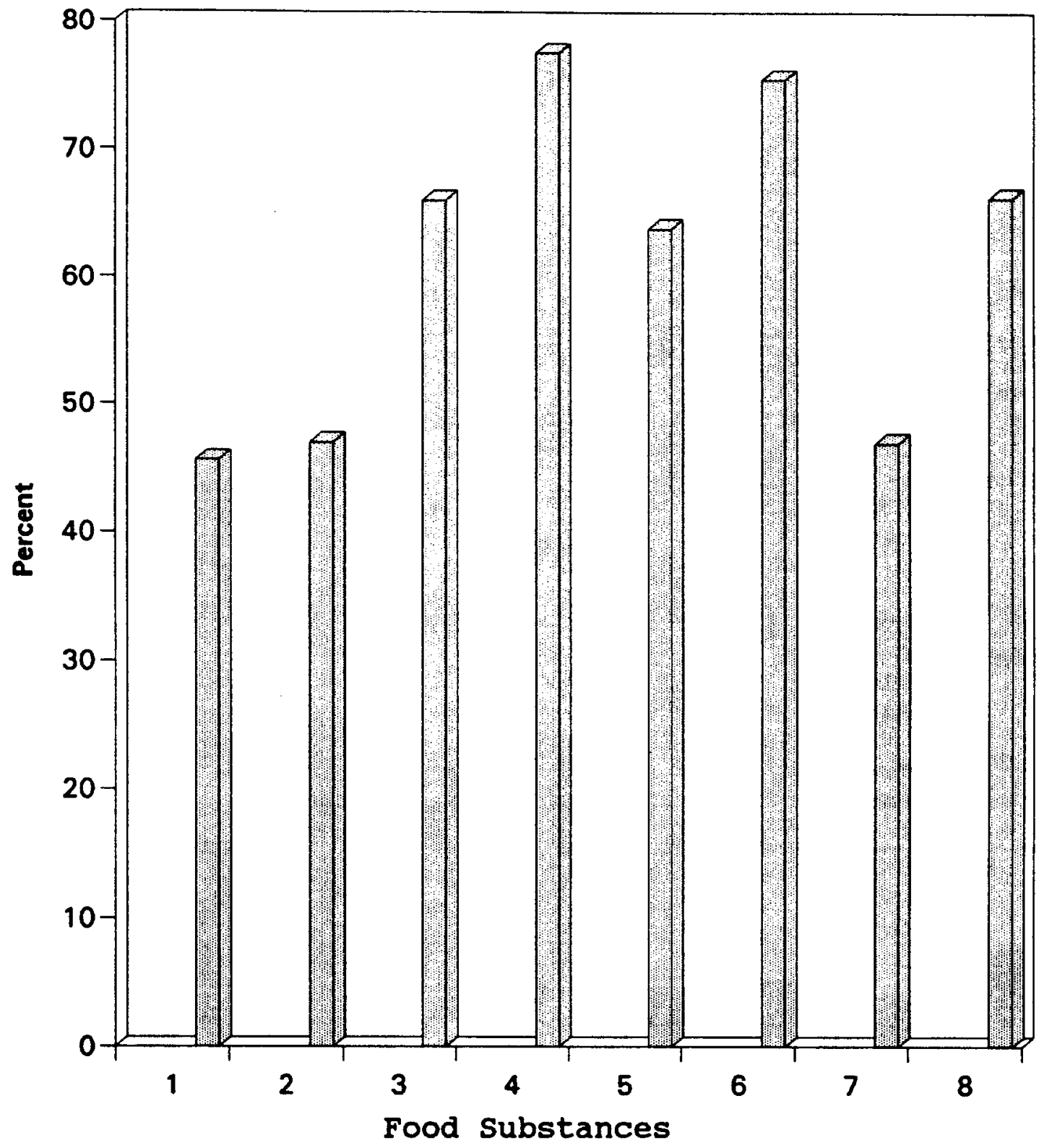

- 1 = Limit Sodium

- 2 =Limit Sugar

- $3=$ Limit Cholesterol

- 4 = Limit Fat

- $5=$ Limit Highly Processed Foods

- $6=$ Limit Alcoholic Beverages

- $7=$ Limit Carbonated Beverages

- 8 = Limit Snack Foods

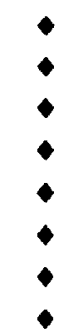

Figure 3. Percent of students Limiting Intake of Food Substances Which Have Had Health

Implications 


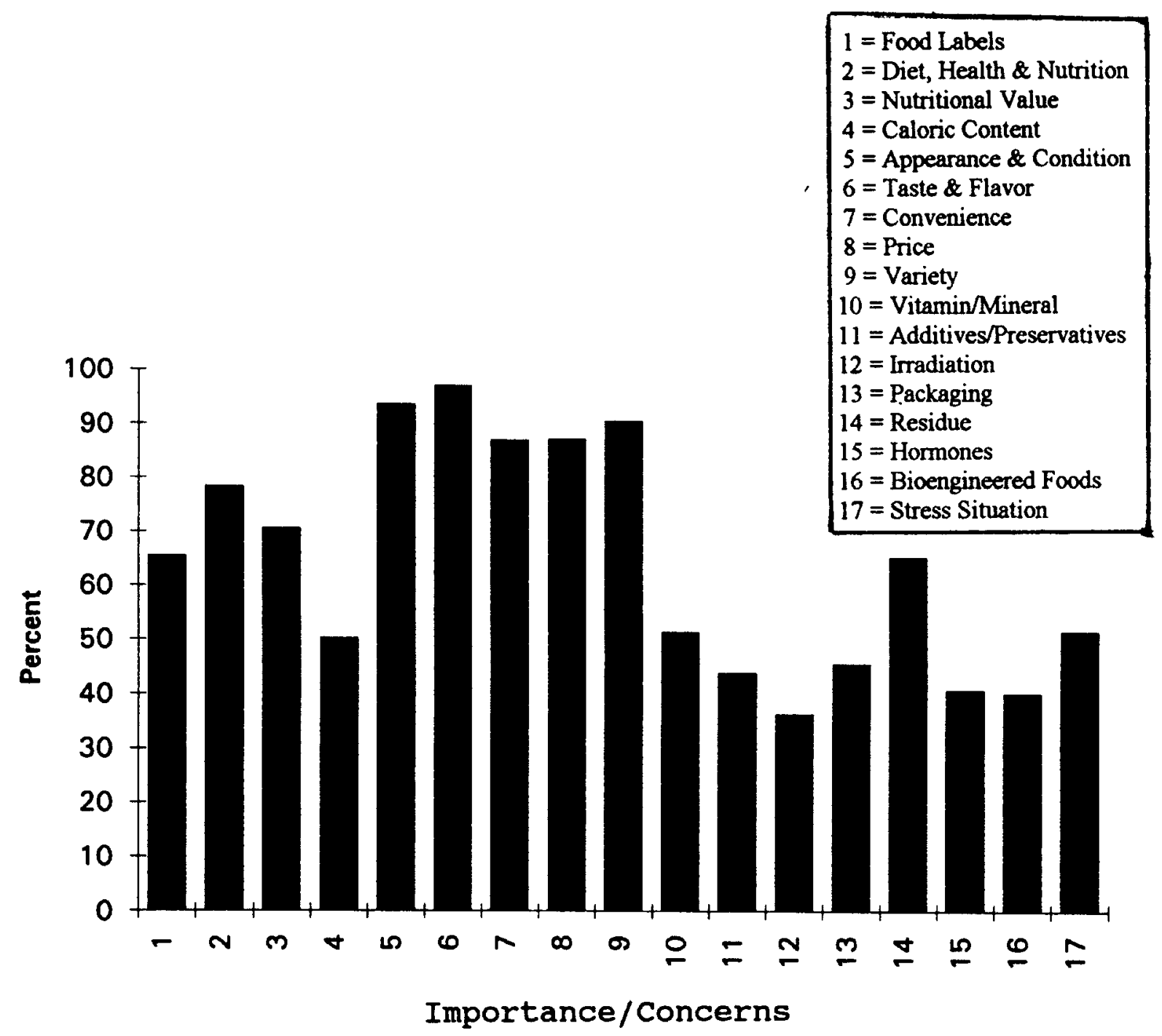

Figure 4. Percent of Students Indicating Importance or Concern of Selected Nutrition Awareness Variables 
Meat Consumption

The food frequency questionnaire consisted of 95 different main dishes containing meat. The subjects were asked to indicate how any times they had eaten these main dishes in the past week or month. If the respondents did not consume a listed dish, they were asked to check the "never" column. There were six columns provided for response on this section of the questionnaire; more than one per week, once per week, more than once per month, once per month, seldom, and never.

The most frequent responses in the more than once per week column were: hamburgers $(21.88)$, pizza with meat (17.08), turkey sandwich (12.68), fried chicken (9.08), baked chicken (9.0\%), spaghetti sauce ( $8.6 \%)$, chicken fried steak (8.3\%), and chicken stir fry $(8.2 \%)$. Responding in the "never" column for ground beef, 69.2 percent answered tamale; cubed beef, 68.8 percent answered K-bob; beef strips, 58.9 percent answered French dip; other beef, 53.3 percent answered cutlet pork, 65.9 percent answered casserole; ham, 56.3 percent answered ham and turkey cordon bleu (Table 4). 
TABLE 4

MEAT CONSUMPTION BY RESPONDENTS DURING THE PAST WEEK OR MONTH

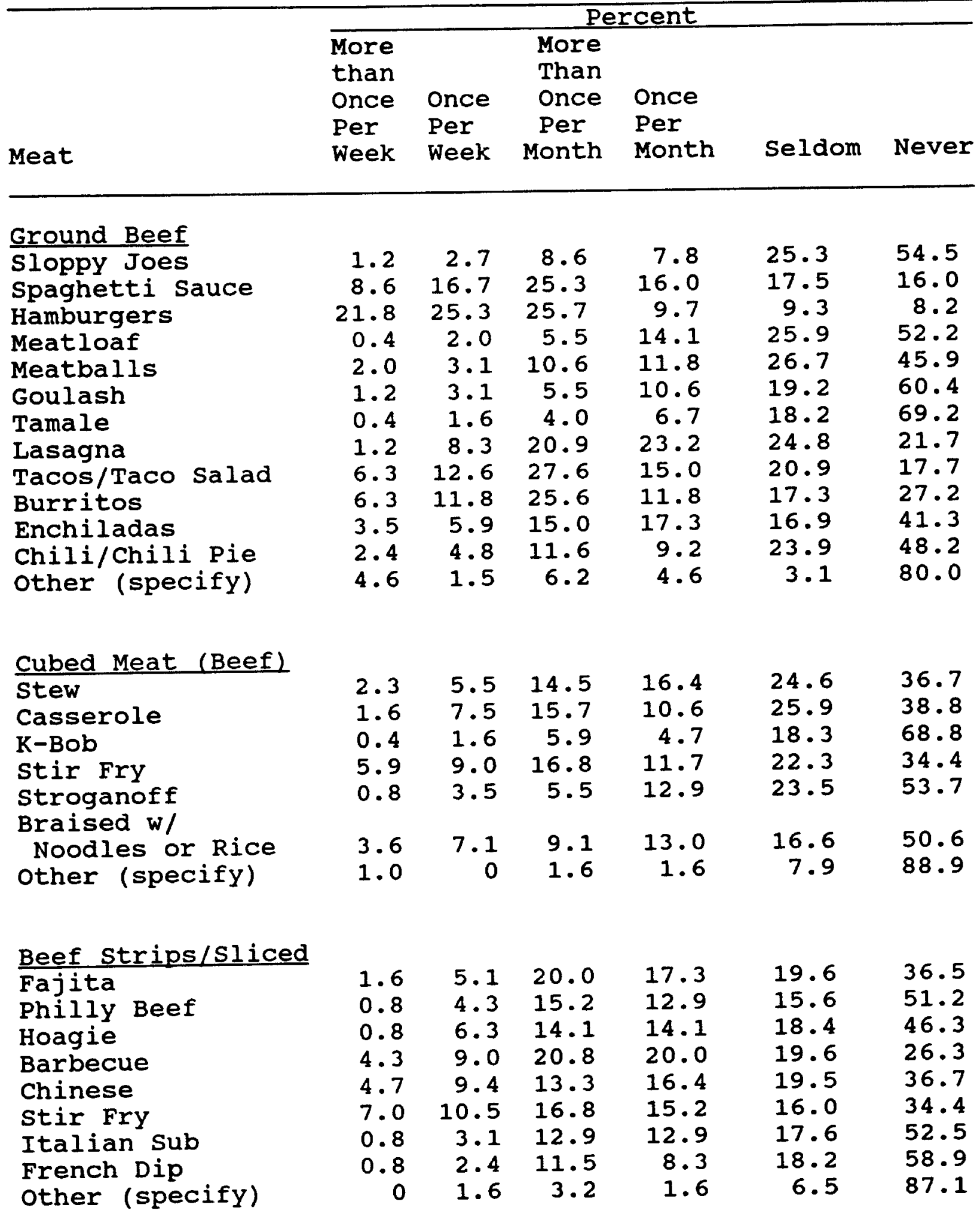


TABLE 4 (Continued)

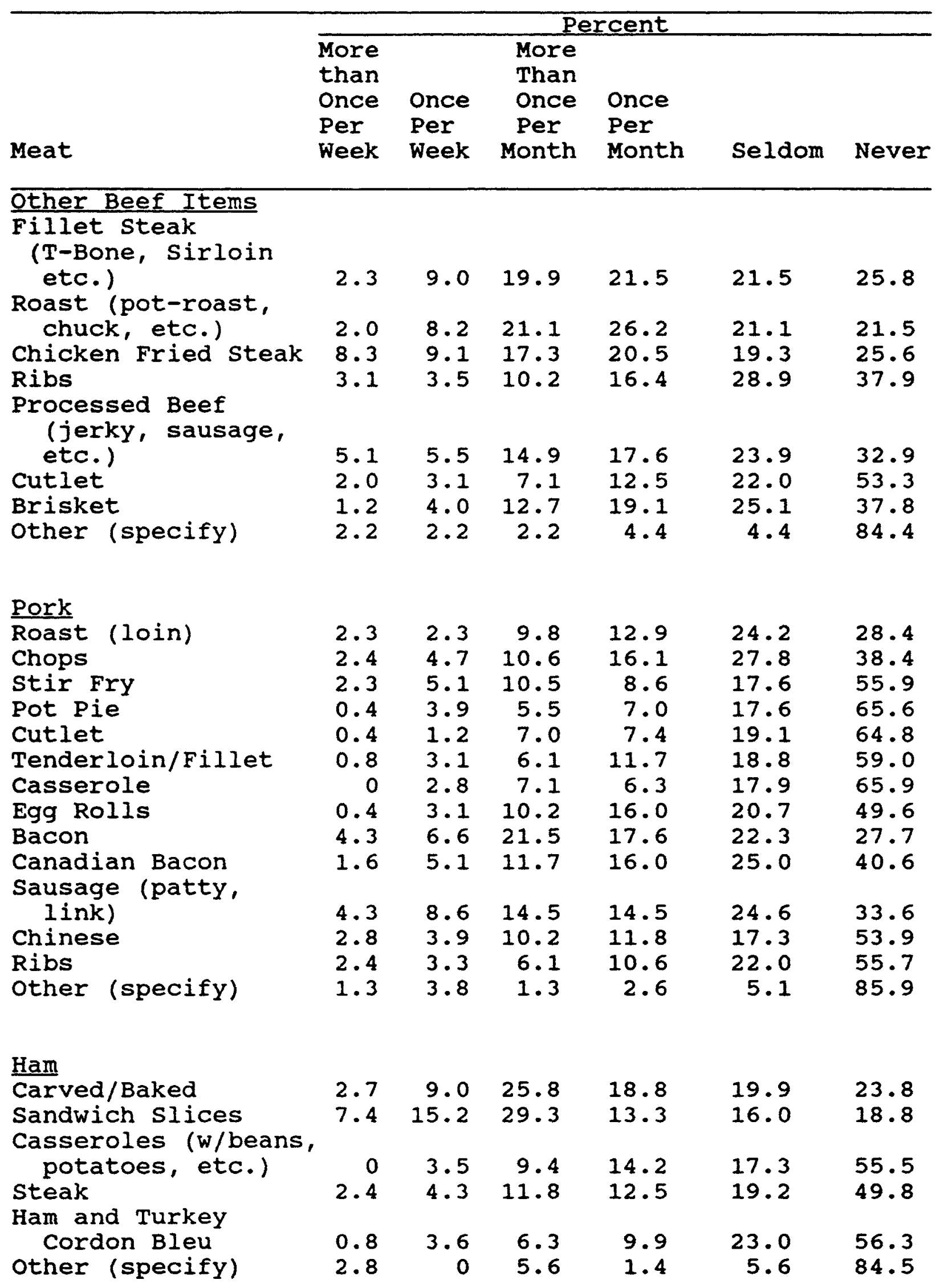


TABLE 4 (Continued)

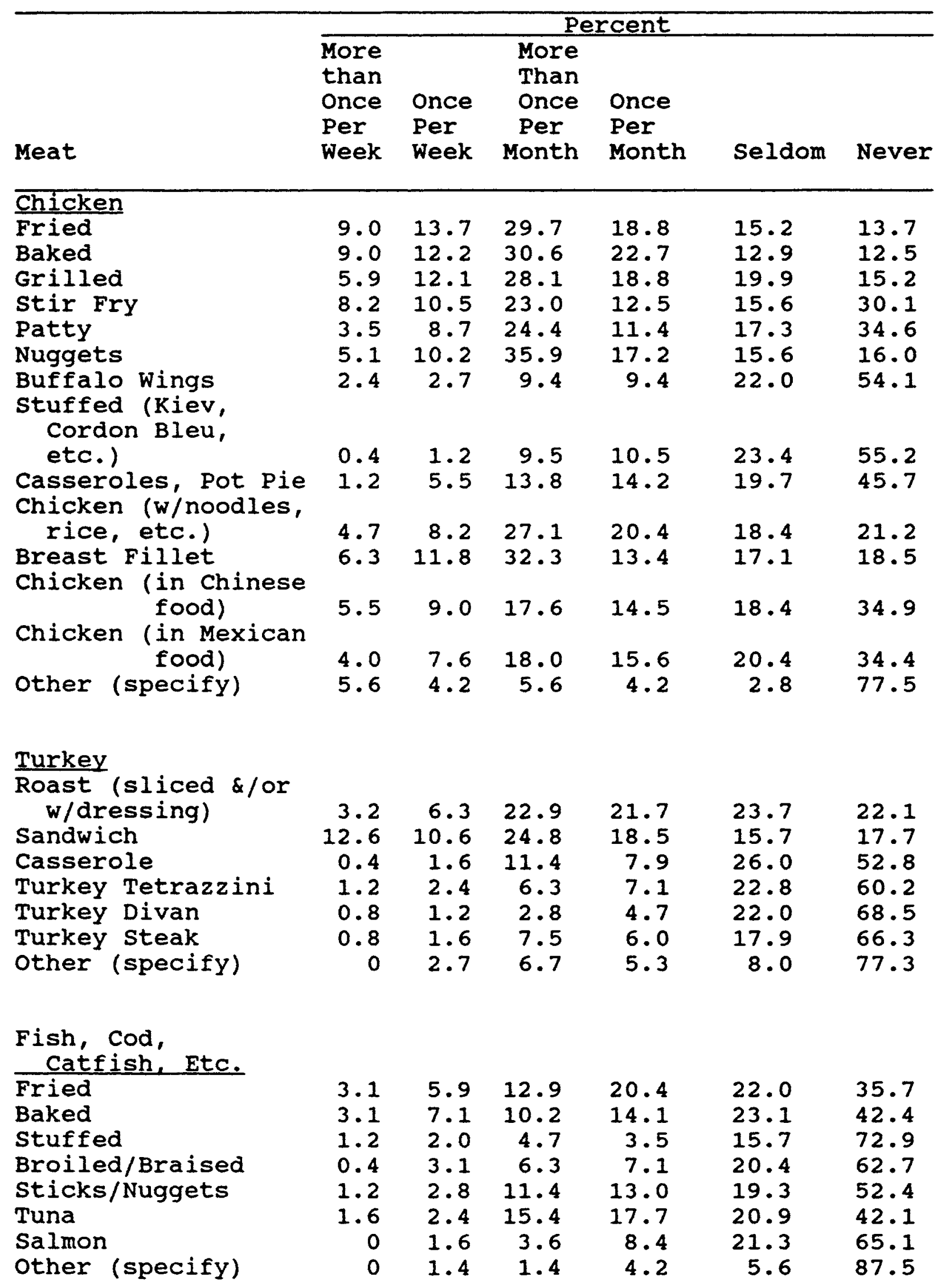


TABLE 4 (Continued)

\begin{tabular}{|c|c|c|c|c|c|c|}
\hline \multirow[b]{2}{*}{ Meat } & \multicolumn{6}{|c|}{ Percent } \\
\hline & $\begin{array}{l}\text { More } \\
\text { than } \\
\text { Once } \\
\text { Per } \\
\text { Week }\end{array}$ & $\begin{array}{l}\text { Once } \\
\text { Per } \\
\text { Week }\end{array}$ & $\begin{array}{l}\text { More } \\
\text { Than } \\
\text { Once } \\
\text { Per } \\
\text { Month }\end{array}$ & $\begin{array}{l}\text { Once } \\
\text { Per } \\
\text { Month }\end{array}$ & Seldom & Never \\
\hline \multicolumn{7}{|l|}{ Shrimp } \\
\hline $\begin{array}{l}\text { Fried } \\
\text { Boiled } \\
\text { Broiled/Braised } \\
\text { Stuffed } \\
\text { Shrimp (w/rice) } \\
\text { Casserole } \\
\text { Other (specify) }\end{array}$ & $\begin{array}{l}2.4 \\
1.6 \\
1.6 \\
0.8 \\
1.6 \\
0.4 \\
1.7\end{array}$ & $\begin{array}{l}4.3 \\
2.4 \\
0.8 \\
1.6 \\
2.4 \\
1.2 \\
4.3\end{array}$ & $\begin{array}{l}9.1 \\
5.1 \\
3.2 \\
1.6 \\
8.2 \\
2.4 \\
0.9\end{array}$ & $\begin{array}{r}15.4 \\
9.8 \\
6.7 \\
6.7 \\
12.5 \\
4.7 \\
2.6\end{array}$ & $\begin{array}{r}24.0 \\
20.9 \\
16.2 \\
12.6 \\
17.6 \\
11.8 \\
8.7\end{array}$ & $\begin{array}{l}44.9 \\
60.2 \\
71.5 \\
76.8 \\
57.6 \\
79.5 \\
81.7\end{array}$ \\
\hline \multicolumn{7}{|l|}{ other seafood } \\
\hline $\begin{array}{l}\text { Lobster } \\
\text { Scallops } \\
\text { Crab } \\
\text { Other (specify) }\end{array}$ & $\begin{array}{r}2.4 \\
0.8 \\
1.6 \\
0\end{array}$ & $\begin{array}{l}0.4 \\
1.2 \\
0.8 \\
0.9\end{array}$ & $\begin{array}{l}2.8 \\
1.2 \\
3.1 \\
0.9\end{array}$ & $\begin{array}{l}4.7 \\
3.5 \\
5.9 \\
0.9\end{array}$ & $\begin{array}{r}15.7 \\
13.8 \\
20.9 \\
6.5\end{array}$ & $\begin{array}{l}74.0 \\
79.5 \\
67.7 \\
90.7\end{array}$ \\
\hline \multicolumn{7}{|l|}{ Miscellaneous } \\
\hline $\begin{array}{l}\text { Hot Dogs } \\
\text { Corn Dogs } \\
\text { Veal } \\
\text { Lamb }\end{array}$ & $\begin{array}{r}5.1 \\
1.6 \\
0 \\
0\end{array}$ & $\begin{array}{l}7.8 \\
4.7 \\
0.8 \\
1.2\end{array}$ & $\begin{array}{r}21.2 \\
15.7 \\
3.9 \\
2.8\end{array}$ & $\begin{array}{r}18.4 \\
18.8 \\
4.3 \\
3.1\end{array}$ & $\begin{array}{l}23 \cdot 9 \\
27.5 \\
13.0 \\
14.2\end{array}$ & $\begin{array}{l}23.5 \\
31.8 \\
78.0 \\
78.7\end{array}$ \\
\hline $\begin{array}{l}\text { Organ Meats } \\
\text { ( Iiver, fries, } \\
\text { etc.) } \\
\text { wild Game } \\
\text { Pizza (w/meat) } \\
\text { Gyro } \\
\text { Other (specify) }\end{array}$ & $\begin{array}{r}0.4 \\
0.4 \\
17.0 \\
0 \\
0\end{array}$ & $\begin{array}{r}1.2 \\
1.6 \\
26.5 \\
1.6 \\
0\end{array}$ & $\begin{array}{r}0.8 \\
4.3 \\
28.9 \\
4.8 \\
6.3\end{array}$ & $\begin{array}{r}2.4 \\
3.9 \\
12.6 \\
7.2 \\
3.1\end{array}$ & $\begin{array}{r}10.2 \\
13.3 \\
9.1 \\
14.4 \\
3.1\end{array}$ & $\begin{array}{r}85.0 \\
76.5 \\
5.9 \\
72.0 \\
87.5\end{array}$ \\
\hline
\end{tabular}


Statistical Analyses

\section{The Instrument}

The research instrument was collapsed into subgroupings for statistical analysis. Data from demographics, nutrition awareness, and consumption questions were collapsed into specific groupings. The meat items in the consumption section were collapsed into 12 groups: ground beef, cubed beef, beef strips, other beef, pork, ham, chicken, turkey, fish, shrimp, seafood, and miscellaneous food items. In addition, ground beef, cubed beef, beef strip and other beef groups were also combined and analyzed as total beef; pork and ham as total pork; chicken and turkey as poultry; shrimp and seafood as total seafood (Table 5). The hypotheses were then analyzed for significance at the $\mathrm{p} \leq 0.05$ level.

\section{Testing of the Hypothesis one}

$\mathrm{Ho}_{1}$ : There will be no significant association between the college students' personal variables and their nutrition awareness: foods to limit, concerns and importance, and consumption patterns. Chi-square values were used to determine the relationships between the respondents' characteristics and the nutrition awareness categories referred to in the null hypothesis. 
TABLE 5

MEAT CONSUMPTION GROUPS FOR STATISTICAL ANALYSIS

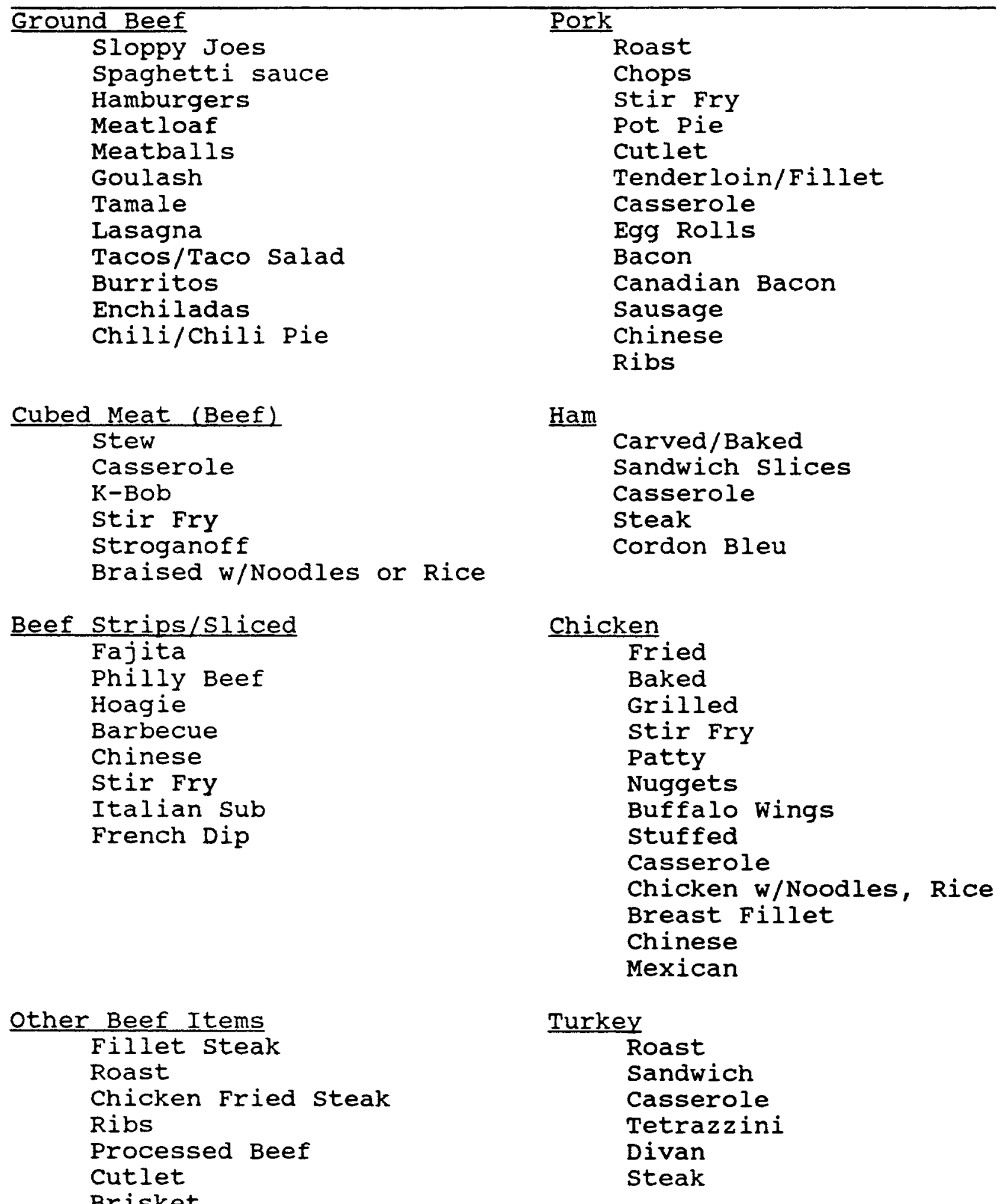


TABLE 5 (Continued)

Fish

Fried

Baked

Stuffed

Broiled/Braised

Sticks/Nuggets

Tuna

Salmon
Shrimp

Fried

Boiled

Broiled/Braised

Stuffed w/Rice

Casserole
Seafood

Lobster

Scallops

crab

\author{
Miscellaneous Meat \\ Hot Dogs \\ Corn Dogs \\ Veal \\ Lamb \\ Organ Meats \\ Wild Game \\ Pizza w/Meat \\ Gyro
}

Nutrition Awareness: Foods/Nutrients to Limit by Gender and Education Level

Chi-square analyses indicated that nine significant associations $(p \leq 0.05)$ existed between respondents' characteristics and nutrition awareness: foods/nutrients to limit (Table 6). The female respondents were more likely to limit sugar $(p=0.004)$, fat $(p=0.004)$, highly processed foods $(p=0.023)$, alcoholic beverages $(p=0.018)$, and snack foods $(p=0.001)$ than the male respondents. Similar findings were found by Hanson, (1994) who studied young adult males and 
TABLE 6

\begin{abstract}
CHI-SQUARE DETERMINATIONS INDICATING ASSOCIATIONS
BETWEEN NUTRITION AWARENESS: FOODS/NUTRIENTS TO

LIMIT AND SELECTED PERSONAL CHARACTERISTICS
\end{abstract}

Nutrition Awareness:

Foods/Nutrients to

Limit

Gender

Education

Level

\title{
Sugar
}

$x^{2}$

df

p

11.424
1.004

14.479

5

.013

Fat

$x^{2}$

df

$\mathrm{p}$

8.486

NS*

1

.004

Highly Processed Foods

$x^{2}$

df

5.193

NS*

$p$

.023

Alcoholic Beverages

$x^{2}$

df

5.575

1

$p$

$$
.018
$$

NS*

Carbonated Beverages

$x^{2}$

df

5.575

NS*

p

1

.018

Snack Foods

$x^{2}$

df

p

12.684
1.001

NS *

\#NS $=$ not significant at $\mathrm{p} \leq 0.05$ 
females enrolled in a freshman level nutrition class. In Hanson's study, females chose diets richer in fiber and specific nutrients that may have a positive effect on health.

Education level was divided into freshman, sophomore, junior, senior, graduate, and special. Level of education was significantly associated $(p=0.013)$ with limitation of sugar (Table 6). Freshmen and seniors were least likely to limit their sugar intake. Freshmen who are away from home for the first time may pay extra attention to eating more meals especially if they are on a 15 or 20 meal plan. Seniors are perhaps more concerned about meeting graduation requirements and may not pay close attention to their diets.

Nutrition Awareness: Concerns and

Importance by Gender, Education

Level, and College

The female respondents were more concerned about the importance of food labels with nutrient information $(p=0.001)$; diet, health, and nutrition $(p=0.001) ;$

nutritional value $(p=0.001)$; caloric content $(p=0.001)$ and appearance and condition $(p=0.004)$ than the male respondents (Table 7). Although the females comprised the group that was more concerned about these nutrition awareness topics, many of the male respondents answered yes to the nutrition awareness questions as well. 
TABLE 7

CHI-SQUARE DETERMINATIONS INDICATING ASSOCIAITONS BETWEEN NUTRITION AWARENESS: CONCERNS AND IMPORTANCE AND SELECTED PERSONAL CHARACTERISTICS

Nutrition Awareness:

Concerns and

Importance

Gender

Education

Level

College

Food Labels with

Nutrient Information

$\mathrm{x}^{2}$

df

$\mathrm{p}$

Diet, Health and

Nutrition

$x^{2}$

df

$\mathrm{p}$

Nutritional Value

$x^{2}$

df

$\mathrm{p}$

\section{Caloric Content}

$x^{2}$

df

$p$

Appearance \&

Condition

$x^{2}$
$d f$
$p$

8.147

1

.004

1

.001

24.854

$$
.001
$$

13.026 .001

18.578

1

.001

NS *

NS*

NS*

17.353

.015

NS *

NS*

NS *

17.047

7 .017

Vitamin \& Mineral content

$x^{2}$

NS *

17.406

df

$p$

5

0.004

*NS $=$ not significant at $\mathrm{p} \leq 0.05$ 
Education Level was significantly associated with vitamin and mineral content $(p=0.004)$. Freshmen, Sophomores, and Special students were least likely to be concerned with the vitamin and mineral content of their food, while the juniors, seniors, and graduate students were more concerned (Table 7). Maybe this is due to the fact that freshmen and sophomores have not had as much nutrition education as the other groups.

colleges at oklahoma state University include: Arts and Science, Business, Human Environmental Sciences, Agriculture, Education, Veterinary Medicine, Engineering, Graduate and special. College was significantly associated with diet, health and nutrition $(p=0.015)$. Although all of the respondents in their respected colleges tended to respond that diet, health and nutrition was important to them, those in the colleges of Human Environmental Sciences, Agriculture, and Education were the most likely to respond positively to this question (Table 7). Caloric content of food was significantly associated with college $(p=0.017)$. The Colleges of Agriculture and Engineering were least likely to be concerned with calories (Table 7). Perhaps this is because these colleges are primarily male dominated and men in this age group are not concerned with calories as much as women. 


\section{Nutrition Awareness: Consumption \\ Patterns by Gender and college}

Gender differences were significant $(p=0.044)$ for servings of meat in a healthy diet (Table 8). The females responded that two servings of meat were included in a healthy diet, whereas males chose three servings. Both of these answers meet the Food Pyramid Guidelines, however, in general, men tend to eat more meat than women. Female respondents answered that their food intake was related to their stress situation $(p=0.001)$. The opposite was true for males (Table 8).

Students from the Colleges of Arts and Science, Human Environmental Sciences, Agriculture and Engineering also reported that their consumption of food was related to their stress situation $(p=0.0250)$ (Table 8). Perhaps they perceive their curriculum as very demanding and therefore, stressful.

Based on the results reported in Tables 6,7 , and 8 , indicating associations between nutrition awareness and the personal variables gender, education level and college, the researcher rejected $\mathrm{HO}_{1}$. If other personal variables such as age and race are considered, then the researcher failed to reject $\mathrm{Ho}_{1}$

Testing of the Hypothesis Two

$\mathrm{Ho}_{2}$ : There will be no significant association between 
TABLE 8

CHI-SQUARE DETERMINATIONS INDICATING ASSOCIATIONS BETWEEN NUTRITION AWARENESS: CONSUMPTION

PATTERNS AND SELECTED PERSONAL

CHARACTERISTICS

Nutrition Awareness:

Consumption

Patterns

Gender

College

Servings of Meat

Each Day for Healthy

Diet

$x^{2}$

11.424

NS*

5

.044

Food Consumption

Related to stress

$x^{2}$

df

14.545

1

16.030

.001

7

.025

${ }^{*} \mathrm{NS}=$ not significant at $\mathrm{p} \leq 0.05$

meat consumption of college students and the selected personal variables: gender, race, age, education level, and college. Student's t-test, analysis of variance (ANOVA) and Duncan's Multiple Range Test were used to determine the relationships between the respondents' characteristics and their meat consumption patterns. 
Meat Consumption by Gender, Race, Education Level and College

The male respondents were most likely to consume other beef, pork, miscellaneous meat, total beef and total pork, while the females were most likely to eat chicken, turkey, and total poultry as a percent of their diet (Table 9). Women may believe that chicken and turkey are healthier than other meat items. Perhaps males associate chicken and turkey as female foods or they just have a taste preference for beef and pork.

There was a significant association between race and the variable shrimp consumption (Table 10). Black students consumed significantly $(p=0.0016)$ more shrimp than the Hispanic students. Although the Asians, Whites and Native Americans consume different amounts of shrimp, it was not significantly different from the amounts consumed by Blacks or Hispanics (Table 11). Shrimp is usually served fried and perhaps Hispanic students prefer their shrimp steamed, broiled or in casseroles or soups.

Analysis of variance (ANOVA) procedures were used to determine significant associations between education level and meat consumption. Respondents classified as graduate students significantly $(p=0.001)$ ate more cubed beef than the other groups (Tables 12, 13). Graduate students are older and may prefer more expensive or substantial servings 
TABLE 9

T-TEST DETERMINATION OF MEAT BY GENDER OF RESPONDENTS

\begin{tabular}{|c|c|c|c|c|c|}
\hline Meat Group & $\frac{\text { Male }}{\text { Mean }}$ & $\frac{(N=106)}{S D}$ & $\frac{\text { Female }}{\text { Mean }}$ & $\frac{(N=151)}{S D}$ & P-Value \\
\hline other Beef & 0.0975 & 0.0565 & 0.0670 & 0.0445 & 0.0001 \\
\hline Pork & 0.1020 & 0.0533 & 0.0864 & 0.0652 & 0.0370 \\
\hline Chicken & 0.1781 & 0.0924 & 0.2377 & 0.1323 & 0.0001 \\
\hline Turkey & 0.0521 & 0.0431 & 0.0671 & 0.0640 & 0.0254 \\
\hline Miscellaneous & 0.0952 & 0.0752 & 0.0731 & 0.0511 & 0.0092 \\
\hline Total Beef & 0.4248 & 0.1208 & 0.3778 & 0.14678 & 0.0053 \\
\hline Total Pork & 0.1623 & 0.0680 & 0.1421 & 0.0881 & 0.0396 \\
\hline Total Poultry & 0.2302 & 0.1044 & 0.3048 & 0.1617 & 0.0001 \\
\hline
\end{tabular}

TABLE 10

ANALYSIS OF VARIANCE (ANOVA) RESULTS FOR SHRIMP CONSUMPTION AND RACE

\begin{tabular}{lrccc}
\hline Source & df & Mean Square & $F$ & $P$ \\
\hline Race & 4 & 0.0047 & 4.49 & 0.0016 \\
Error & 250 & 0.0011 & & \\
Total & 254 & & &
\end{tabular}


TABLE 11

DUNCAN'S MULTIPLE RANGE TEST FOR RACE AND SHRIMP CONSUMPTION

\begin{tabular}{lccc}
\hline Race & N & Mean & Grouping* \\
\hline Black & 12 & 0.05 & A \\
Asian/Oriental & 20 & 0.04 & AB \\
White & 207 & 0.02 & AB \\
Native American & 15 & 0.01 & B \\
Hispanic & 1 & 0.00 & \\
$\begin{array}{l}\text { *Means with the same letter are not significantly different } \\
\text { at the } 0.05 \text { level }\end{array}$
\end{tabular}

TABLE 12

ANALYSIS OF VARIANCE (ANOVA) RESULTS FOR EDUCATION AND CUBED BEEF CONSUMPTION

\begin{tabular}{lrcccc}
\hline Source & df & Mean Square & F & P \\
\hline Educational Level & 5 & 0.027 & 5.64 & 0.0001 \\
Error & 249 & 0.005 & & \\
Total & 254 & & & \\
\end{tabular}


TABLE 13

DUNCAN'S MULTIPLE RANGE TEST FOR EDUCATION AND CUBED BEEF CONSUMPTION

\begin{tabular}{|c|c|c|c|}
\hline Education & $\mathrm{N}$ & Mean & Grouping* \\
\hline Graduate & 8 & 0.18 & $A$ \\
\hline Business & 65 & 0.06 & B \\
\hline Senior & 38 & 0.06 & B \\
\hline Junior & 39 & 0.05 & B \\
\hline Special & 2 & 0.05 & B \\
\hline Freshman & 103 & 0.05 & B \\
\hline
\end{tabular}

of meat as compared with the undergraduates who prefer ground beef.

Significant association $(p=0.0008)$ existed between the College of Agriculture and the Graduate college with regard to other beef consumption. Students in the college of Agriculture consumed more other beef items than students from the Graduate college. Although the colleges of Business, Arts and Science, Education, and Human Environmental sciences consume different amounts of other 
beef, it was not significantly different from the amounts consumed by the Colleges of Agriculture, Engineering, Special or Graduate (Tables 14, 15). Perhaps this is because students in the college of Agriculture are most likely to eat steak, whereas graduate students may not be able to afford this luxury item.

Based on the results reported in Tables 9-15 indicating associations between meat consumption and the personal variables gender, race, education level and college, the researcher rejected $\mathrm{HO}_{2}$. If the other personal variable age is considered, then the researcher failed to reject $\mathrm{Ho}_{2}$.

Testing of the Hypothesis Three

$\mathrm{Ho}_{3}$ : There will be no significant association between meat consumption patterns of college students and their nutrition awareness: foods to limit, concerns and importance, and consumption patterns. Student's t-test, analysis of variance (ANOVA) and Duncan's Multiple Range Test were used to determine the relationships between the respondents' nutrition awareness characteristics and their meat consumption patterns. 
TABLE 14

ANALYSIS OF VARIANCE (ANOVA) RESULTS FOR OTHER BEEF CONSUMPTION AND COLLEGE

\begin{tabular}{lcccc}
\hline Source & df & Mean Square & $F$ & $P$ \\
\hline College & 7 & 0.0093 & 3.68 & 0.0008 \\
Error & 246 & 0.0025 & & \\
Total & 256 & & & \\
\end{tabular}

TABLE 15

DUNCAN'S MULTIPLE RANGE TEST FOR OTHER

BEEF CONSUMPTION AND COLLEGE

\begin{tabular}{lccc}
\hline Education & $\mathrm{N}$ & Mean & Grouping* \\
\hline Agriculture & 21 & 0.11 & $\mathrm{~A}$ \\
Engineering & 50 & 0.10 & $\mathrm{~A}$ \\
Special & 2 & 0.10 & $\mathrm{~A}$ \\
Business & 52 & 0.08 & $\mathrm{AB}$ \\
Arts \& Science & 84 & 0.07 & $\mathrm{AB}$ \\
Education & 21 & 0.07 & $\mathrm{AB}$ \\
Human Environmental & & 0.06 & $\mathrm{AB}$ \\
$\quad$ Sciences & 21 & 0.03 & $\mathrm{~B}$ \\
Graduate & 3 & 503 &
\end{tabular}

* Means with the same letter are not significantly different at the 0.05 level 
Meat consumption by Limit: Sodium, Sugar, Cholesterol and Fat

Those students who consumed more other beef $(p=0.0055$ and ham $(p=0.0265)$ were least likely to limit sodium in their diet (Table 16). Students limiting their sugar intake consumed more total seafood $(p=0.0468)$. Those students not concerned with limiting sugar ate more other beef $(p=0.0027)$, turkey $(p=0.0178)$, and miscellaneous meat $(p=0.0231)$ (Table 17). Students who ate more chicken $(p=0.0131)$, turkey $(p=0.0104)$, and poultry $(p=0.0008)$ were most likely to limit cholesterol in their diet, while those eating more other beef $(p=0.0195)$, and total beef $(p=0.0481)$ were not (Table 18). Limiting fat intake was expressed by respondents who consumed more cubed beef $(p=0.0287)$, chicken $(p=0.0059)$ and turkey $(p=0.0344)$. Those not concerned with limiting fat intake ate more other beef $(p=0.0388)$, pork $(p=0.0314)$, and miscellaneous meat $(p=0.0231)$ (Table 19). It is possible that in general, the students not concerned with limiting sugar are not on a diet. Also, as expected, the respondents who were limiting cholesterol and fat watched their diet and ate healthier meats such as chicken and turkey. 
TABLE 16

T-TEST DETERMINATION ON CONSUMPTION OF MEAT BY NUTRITION AWARENESS: LIMIT SODIUM

\begin{tabular}{|c|c|c|c|c|c|}
\hline & Yes & $(\mathrm{N}=115)$ & No & $(\mathrm{N}=137)$ & \\
\hline Meat Group & Mean & SD & Mean & SD & P-Value \\
\hline Other Beef & 0.0700 & 0.0483 & 0.0880 & 0.0533 & 0.0055 \\
\hline Ham & 0.0509 & 0.0452 & 0.0633 & 0.0439 & 0.0265 \\
\hline
\end{tabular}

TABLE 17

T-TEST DETERMINATION ON CONSUMPTION OF MEAT

BY NUTRITION AWARENESS: LIMIT SUGAR

\begin{tabular}{lcccccc}
\hline & Yes & $(N=118)$ & No & $(N=133)$ & \\
\cline { 2 - 5 } Meat Group & Mean & SD & & Mean & SD & P-Value \\
\hline Other Beef & 0.0725 & 0.0435 & 0.0857 & 0.0572 & 0.0388 \\
Turkey & 0.0706 & 0.0696 & 0.0830 & 0.0419 & 0.0178 \\
Miscellaneous & 0.0731 & 0.6568 & 0.0911 & 0.0680 & 0.0231 \\
Total seafood & 0.1015 & 0.1385 & 0.0747 & 0.0650 & 0.0468 \\
\hline
\end{tabular}


TABLE 18

T-TEST DETERMINATION ON CONSUMPTION OF MEAT BY NUTRITION AWARENESS: LIMIT CHOLESTEROL

\begin{tabular}{lccccc}
\hline & Yes & $(N=167)$ & No & $(N=86)$ & \\
\cline { 2 - 5 } Meat Group & Mean & SD & Mean & SD & P-Value \\
\hline Other Beef & 0.0737 & 0.0460 & 0.0914 & 0.0609 & 0.0195 \\
Chicken & 0.2269 & 0.1274 & 0.1842 & 0.1009 & 0.0038 \\
Turkey & 0.0669 & 0.0630 & 0.0499 & 0.0411 & 0.0104 \\
Total Beef & 0.3852 & 0.1321 & 0.4231 & 0.1484 & 0.0481 \\
Poultry & 0.2938 & 0.1530 & 0.2341 & 0.1211 & 0.0008 \\
\hline
\end{tabular}

TABLE 19

T-TEST DETERMINATION ON CONSUMPTION OF MEAT BY NUTRITION AWARENESS: LIMIT FAT

\begin{tabular}{lccccc}
\hline & \multicolumn{2}{c}{ Yes $(\mathrm{N}=197)$} & No & $(\mathrm{N}=57)$ & \\
\cline { 2 - 5 } Meat Group & Mean & $\mathrm{SD}$ & Mean & $\mathrm{SD}$ & P-Value \\
\hline Cubed Beef & 0.0598 & 0.0805 & 0.0437 & 0.0342 & 0.0287 \\
Other Beef & 0.0728 & 0.0456 & 0.0998 & 0.0649 & 0.0043 \\
Pork & 0.0882 & 0.0627 & 0.1063 & 0.0521 & 0.0314 \\
Chicken & 0.2241 & 0.1228 & 0.1775 & 0.1061 & 0.0059 \\
Turkey & 0.0646 & 0.0605 & 0.0498 & 0.0406 & 0.0344 \\
Miscellaneous & 0.0765 & 0.0561 & 0.1034 & 0.0808 & 0.0213 \\
\hline
\end{tabular}




\author{
Meat Consumption by Limit: Highly \\ Processed Foods, Alcoholic \\ Beverages, Carbonated \\ Beverages and snack
}

Foods

Respondents who ate more chicken $(p=0.0001)$, fish $(p=0.0111)$, seafood $(p=0.0314)$, poultry $(0.0002)$ and total seafood $(p=0.0026)$ were most likely to limit highly processed foods, while those consuming more miscellaneous meat $(p=0.0015)$, total beef $(p=0.0388)$, and total pork $(p=0.0001)$ were not (Table 20). Respondents who chose to limit alcoholic beverages ate more ground beef $(p=0.0054)$ (Table 21). Those who were not likely to limit alcoholic beverages consumed more beef strips $(p=0.0456)$, and shrimp $(p=0.0314)$ (Table 21). students who consumed more miscellaneous meat $(p=0.0011)$, were not likely to limit their carbonated beverage intake (Table 22). Respondents that ate more other beef $(p=0.0008)$ and pork $(p=0.0238)$ did not limit snack foods (Table 23). As expected, those who ate more miscellaneous meat did not limit highly processed foods because hotdogs were in this category. Perhaps those who chose to limit alcoholic beverages and carbonated beverages are not dieters therefore, they do not watch their food intake and those not limiting snack foods ate other beef and pork possibly because food intake was not a concern to them also. 
TABLE 20

T-TEST DETERMINATION ON CONSUMPTION OF MEAT BY NUTRITION AWARENESS: LIMIT HIGHLY PROCESSED FOOD

\begin{tabular}{lccccc}
\hline & Yes & $(\mathrm{N}=164)$ & No & $(\mathrm{N}=93)$ & \\
\cline { 2 - 5 } Meat Group & Mean & SD & Mean & SD & P-Value \\
\hline Chicken & 0.2325 & 0.1330 & 0.1789 & 0.0864 & 0.0001 \\
Fish & 0.0623 & 0.1001 & 0.0400 & 0.0369 & 0.0111 \\
Seafood & 0.0103 & 0.0260 & 0.0053 & 0.0107 & 0.0314 \\
Miscellaneous & 0.0717 & 0.0504 & 0.1007 & 0.0775 & 0.0015 \\
Total Beef & 0.3852 & 0.1554 & 0.4182 & 0.0988 & 0.0388 \\
Total Pork & 0.1329 & 0.0811 & 0.1815 & 0.0708 & 0.0001 \\
Poultry & 0.2700 & 0.1596 & 0.2335 & 0.1055 & 0.0002 \\
Total Seafood & 0.1010 & 0.1266 & 0.0661 & 0.0561 & 0.0026 \\
\hline
\end{tabular}

TABLE 21

T-TEST DETERMINATION ON CONSUMPTION OF MEAT BY NUTRITION AWARENESS: LIMIT ALCOHOLIC BEVERAGES

\begin{tabular}{lcccccc}
\hline & Yes & $(\mathrm{N}=194)$ & & No & $(\mathrm{N}=63)$ & \\
\cline { 2 - 5 } Meat Group & Mean & $\mathrm{SD}$ & & Mean & SD & P-Value \\
\hline Ground Beef & 0.1903 & 0.1214 & 0.1518 & 0.0835 & 0.0054 \\
Beef Strips & 0.0772 & 0.0503 & 0.0917 & 0.0490 & 0.0456 \\
Shrimp & 0.0224 & 0.0284 & 0.0353 & 0.0438 & 0.0314 \\
\hline
\end{tabular}


TABLE 22

T-TEST DETERMINATION ON CONSUMPTION OF MEAT BY NUTRITION AWARENESS: LIMIT CARBONATED BEVERAGES

\begin{tabular}{lcccccc}
\hline \multirow{2}{*}{ Meat Group } & Yes & $(\mathrm{N}=125)$ & & No & $(\mathrm{N}=131)$ & \\
\cline { 2 - 5 } & Mean & SD & & Mean & SD & P-Value \\
\hline Miscellaneous & 0.0693 & 0.0490 & 0.0947 & 0.0721 & 0.0011 \\
\hline
\end{tabular}

TABLE 23

T-TEST DETERMINATION ON CONSUMPTION OF MEAT BY NUTRITION AWARENESS: LIMIT SNACK FOODS

\begin{tabular}{lcccccc}
\hline & Yes & $(\mathrm{N}=169)$ & & No & $(\mathrm{N}=86)$ & \\
\cline { 2 - 5 } Meat Group & Mean & SD & & Mean & SD & P-Value \\
\hline Other Beef & 0.0530 & 0.0041 & 0.0941 & 0.0473 & 0.0008 \\
Pork & 0.0868 & 0.0580 & 0.1057 & 0.0651 & 0.0238 \\
\hline
\end{tabular}


Meat Consumption by Importance or Concern

for Food Labels with Nutrient

Information and Diet,

Health and Nutrition

The students who consumed more chicken $(p=0.0017)$, turkey $(p=0.0145)$, fish $(p=0.0379)$, seafood $(p=0.0388)$, poultry $(p=0.0003)$ and total seafood $(p=0.0460)$ were most likely to be concerned about foods labels with nutrient information and those students consuming more other beef $(p=0.0001)$, miscellaneous meat $(p=0.0203)$, pork $(p=0.0367)$, total beef $(p=0.0019)$, and total pork $(p=0.0486)$ were not (Table 24). Importance or concern with diet, health, and nutrition was significantly associated with higher consumption of chicken $(p=0.0127)$, turkey $(p=0.0263)$, and poultry $(p=0.0032)$, while those eating more cubed beef $(p=0.0099)$ and miscellaneous meat $(p=0.0063)$ were not as concerned with the importance of diet, health, and nutrition (Table 25). Based on these results it appears that the respondents who were concerned about food labels also ate healthier cuts of meat. In addition, most of those same respondents were also concerned with diet, health, and nutrition. 
TABLE 24

T-TEST DETERMINATION ON CONSUMPTION OF MEAT BY NUTRITION AWARENESS: IMPORTANCE OR CONCERN FOR FOOD LABELS WITH NUTRIENT INFORMATION

\begin{tabular}{lcccccc}
\hline & \multicolumn{2}{c}{ Yes $(\mathrm{N}=167)$} & No & $(\mathrm{N}=88)$ & \\
\cline { 2 - 5 } Meat Group & Mean & $\mathrm{SD}$ & Mean & $\mathrm{SD}$ & P-Value \\
\hline Other Beef & 0.0686 & 0.0419 & 0.1005 & 0.0624 & 0.0001 \\
Pork & 0.0870 & 0.0609 & 0.1038 & 0.0607 & 0.0367 \\
Chicken & 0.2276 & 0.1322 & 0.1831 & 0.0895 & 0.0017 \\
Turkey & 0.0667 & 0.0629 & 0.5055 & 0.0413 & 0.0145 \\
Fish & 0.0607 & 0.0995 & 0.0425 & 0.0377 & 0.0379 \\
Seafood & 0.0103 & 0.0256 & 0.0054 & 0.0117 & 0.0388 \\
Miscellaneous & 0.0750 & 0.0549 & 0.0963 & 0.0750 & 0.0203 \\
Total Beef & 0.3785 & 0.1429 & 0.4328 & 0.1241 & 0.0019 \\
Total Pork & 0.1435 & 0.0836 & 0.1639 & 0.0749 & 0.0486 \\
Poultry & 0.2943 & 0.1599 & 0.2336 & 0.1039 & 0.0003 \\
Total Seafood & 0.0966 & 0.1262 & 0.0734 & 0.0582 & 0.0460 \\
\hline & & & & & \\
\hline
\end{tabular}


TABLE 25

T-TEST DETERMINATION ON CONSUMPTION OF MEAT BY NUTRITION AWARENESS: IMPORTANCE OR CONCERN FOR

DIET, HEALTH, AND NUTRITION

\begin{tabular}{lcccccc}
\hline & Yes & $(\mathrm{N}=200)$ & & No & $(\mathrm{N}=55)$ & \\
\cline { 2 - 6 } Meat Group & Mean & SD & & Mean & SD & P-Value \\
\hline Cubed Beef & 0.0600 & 0.0805 & 0.0418 & 0.0298 & 0.0099 \\
Chicken & 0.2222 & 0.1240 & 0.1814 & 0.1001 & 0.0127 \\
Turkey & 0.0642 & 0.0610 & 0.0494 & 0.0369 & 0.0263 \\
Miscellaneous & 0.0750 & 0.0554 & 0.1078 & 0.0811 & 0.0063 \\
Poultry & 0.2864 & 0.1510 & 0.2308 & 0.1119 & 0.0032
\end{tabular}

\author{
Consumption of Meat by Importance or \\ Concern for Nutritional Value, \\ Caloric content and Vitamin \\ and Mineral Content
}

Nutritional Value was important or of concern to respondents consuming more chicken $(p=0.0052)$, turkey $(p=0.0028)$, fish $(p=0.0063)$, poultry $(p=0.0005)$, and total seafood $(p=0.0192)$. Those students eating more other beef $(p=0.0001)$, pork $(p=0.0365)$, miscellaneous meat $(p=0.0078)$, and total beef $(p=0.0030)$ were not concerned with the 
importance of nutritional value (Table 26). Importance of caloric content was indicated by students eating more chicken $(p=0.0003)$, and poultry $(p=0.0002)$ while those eating more other beef $(p=0.0001)$ and total beef $(p=0.0009)$ were not (Table 27). Significant association existed between concern for vitamin and mineral content of foods and those who consumed more turkey $(p=0.0003)$, fish $(p=0.0352)$, poultry $(p=0.0151)$ and total seafood $(p=0.0146)$. students eating more ground beef $(p=0.0440)$, miscellaneous meat $(p=0.0238$, and total beef $(p=0.0054)$, however, were not concerned about vitamin and mineral content of foods (Table 28). As expected, those students who ate cuts of meats perceived as healthier were concerned with nutritional value, caloric content, and vitamin and mineral content of their diet. 
TABLE 26

T-TEST DETERMINATION ON CONSUMPTION OF MEAT BY NUTRITION AWARENESS: IMPORTANCE OR CONCERN FOR NUTRITIONAL VALUE

\begin{tabular}{lcccccc}
\hline & Yes & $(\mathrm{N}=18)$ & & No & $(\mathrm{N}=75)$ & \\
\cline { 2 - 4 } Meat Group & Mean & SD & & Mean & SD & P-Value \\
\hline Other Beef & 0.0691 & 0.0454 & 0.1044 & 0.0886 & 0.0001 \\
Pork & 0.0876 & 0.0603 & 0.1054 & 0.0615 & 0.0365 \\
Chicken & 0.2253 & 0.1241 & 0.1817 & 0.1068 & 0.0052 \\
Turkey & 0.0666 & 0.0624 & 0.0475 & 0.0374 & 0.0028 \\
Fish & 0.0610 & 0.0967 & 0.0386 & 0.0319 & 0.0063 \\
Miscellaneous & 0.0747 & 0.0561 & 0.1007 & 0.0748 & 0.0078 \\
Total Beef & 0.3811 & 0.1395 & 0.4361 & 0.1294 & 0.0030 \\
Poultry & 0.2919 & 0.1520 & 0.2291 & 0.1180 & 0.0005 \\
Total Seafood & 0.0962 & 0.1227 & 0.0700 & 0.0551 & 0.0192 \\
\hline
\end{tabular}


TABLE 27

T-TEST DETERMINATION ON CONSUMPTION OF MEAT BY NUTRITION AWARENESS: IMPORTANCE OR CONCERN

FOR CALORIC CONTENT

\begin{tabular}{lcccccc}
\hline & Yes & $(\mathrm{N}=128)$ & & No & $(\mathrm{N}=126)$ & \\
\cline { 2 - 5 } Meat Group & Mean & SD & & Mean & SD & P-Value \\
\hline Other Beef & 0.0667 & 0.0450 & 0.0928 & 0.0557 & 0.0001 \\
Chicken & 0.2387 & 0.1324 & 0.1847 & 0.1017 & 0.0003 \\
Total Beef & 0.3697 & 0.1265 & 0.4270 & 0.1447 & 0.0009 \\
Poultry & 0.3060 & 0.1604 & 0.2391 & 0.1208 & 0.0002 \\
\hline
\end{tabular}

TABLE 28

T-TEST DETERMINATION ON CONSUMPTION OF MEAT BY NUTRITION AWARENESS: IMPORTANCE OR CONCERN FOR VITAMIN AND MINERAL CONTENT

\begin{tabular}{lcccccc}
\hline & \multicolumn{1}{c}{ Yes } & $(\mathrm{N}=132)$ & & No & $(\mathrm{N}=124)$ & \\
\cline { 2 - 5 } Meat Group & Mean & SD & & Mean & SD & P-Value \\
\hline Ground Beef & 0.1670 & 0.1275 & 0.1956 & 0.0973 & 0.0440 \\
Turkey & 0.0730 & 0.0677 & 0.0481 & 0.0385 & 0.0003 \\
Fish & 0.0648 & 0.1089 & 0.0433 & 0.0406 & 0.0352 \\
Miscellaneous & 0.0737 & 0.0601 & 0.0915 & 0.0652 & 0.0238 \\
Total Beef & 0.3742 & 0.1544 & 0.4218 & 0.1152 & 0.0054 \\
Poultry & 0.2947 & 0.1597 & 0.2509 & 0.1253 & 0.0151 \\
Total Seafood & 0.1042 & 0.1382 & 0.0719 & 0.0571 & 0.0146 \\
\hline
\end{tabular}




\title{
Consumption of Meat by Importance or \\ Concern for Appearance and \\ Condition and Taste \\ and Flavor
}

Respondents who consumed more ground beef $(p=0.0493)$ were most likely to be concerned with the appearance and condition of their food (Table 29). Taste and flavor were considered important by the students eating more poultry $(p=0.0464)$ (Table 30). Perhaps these were the female respondents who generally payed more attention to the foods they eat.

\author{
Consumption of Meat by Importance \\ or Concern for Convenience \\ and Price
}

Convenience was perceived as important to those students consuming miscellaneous meat $(p=0.0015)$ (Table 31). Respondents who indicated that price was important ate more ground beef $(p=0.0001)$ and miscellaneous meat $(p=0.0022)$ (Table 32). Many of the meats in the miscellaneous meat group are foods that may be considered as fairly easy to prepare, therefore it is not surprising that for these students, convenience was important. Ground beef and miscellaneous meats are some of the less expensive meats, therefore it is not surprising that price is a concern for the respondents who purchased these meat items. 
TABLE 29

T-TEST DETERMINATION ON CONSUMPTION OF MEAT BY NUTRITION AWARENESS: IMPORTANCE OR CONCERN FOR APPEARANCE AND CONDITION

\begin{tabular}{lcccccc}
\hline \multirow{2}{*}{ Meat Group } & Yes & $(\mathrm{N}=240)$ & & No & $(\mathrm{N}=16)$ & \\
\cline { 2 - 5 } & Mean & SD & & Mean & SD & P-Value \\
\hline Ground Beef & 0.1844 & 0.1152 & 0.1327 & 0.0936 & 0.0493 \\
\hline
\end{tabular}

TABLE 30

T-TEST DETERMINATION ON CONSUMPTION OF MEAT BY NUTRITION AWARENESS: IMPORTANCE OR CONCERN FOR TASTE AND FLAVOR

\begin{tabular}{lcccccc}
\hline \multirow{2}{*}{ Meat Group } & Yes & $(\mathrm{N}=249)$ & & No & $(\mathrm{N}=7)$ & \\
\cline { 2 - 5 } & Mean & SD & & Mean & SD & P-Value \\
\hline Poultry & 0.2745 & 0.1473 & 0.2519 & 0.0657 & 0.0464 \\
\hline
\end{tabular}


TABLE 31

T-TEST DETERMINATION ON CONSUMPTION OF MEAT BY NUTRITION AWARENESS: IMPORTANCE OR CONCERN FOR CONVENIENCE

\begin{tabular}{lcccccc} 
& Mes & $(\mathrm{N}=223)$ & & No & $(\mathrm{N}=33)$ & \\
\cline { 2 - 5 } & Mean & $\mathrm{SD}$ & & Mean & $\mathrm{SD}$ & P-Value \\
\hline Miscellaneous & 0.0878 & 0.0652 & 0.0586 & 0.0397 & 0.0015
\end{tabular}

TABLE 32

T-TEST DETERMINATION ON CONSUMPTION OF MEAT BY NUTRITION AWARENESS: IMPORTANCE OR CONCERN FOR PRICE

\begin{tabular}{lcccccc}
\hline & Yes & $(\mathrm{N}=167)$ & & No & $(\mathrm{N}=88)$ & \\
\cline { 2 - 5 } Meat Group & Mean & $\mathrm{SD}$ & Mean & SD & P-Value \\
\hline Ground Beef & 0.1892 & 0.1183 & 0.1348 & 0.0618 & 0.0001 \\
Miscellaneous & 0.0859 & 0.0656 & 0.0620 & 0.0341 & 0.0022
\end{tabular}




\section{Meat Consumption by Importance or Concern for Variety, and Packaging}

Variety was important or of concern to the respondents consuming more fish $(p=0.0178)$ and total seafood $(p=0.0001)$ (Table 33). Those who considered packaging as important consumed more other beef $(p=0.0231)$ while those eating more cubed beef $(p=0.0001)$ and fish $(p=0.0001)$ were not concerned with this variable (Table 34 ). Perhaps respondents who ate more $f$ ish and seafood were concerned with variety because these foods are usually served as fried items in the cafeteria. Other beef and fish are somewhat expensive, therefore students want to make sure that these are well packaged when purchased to ensure good quality.

\section{Meat Consumption by Importance or Concern for Additives and Preservatives, Irradiation, Residue, Hormones, and Bioengineered Foods}

Importance or concern for additives and preservatives were indicated by respondents consuming more turkey $(p=0.0251)$, seafood $(p=0.0440)$, poultry $(p=0.0249)$ and total seafood $(p=0.0258)$. In contrast, students who ate more ground beef $(p=0.0105)$, other beef $(p=0.0004)$, pork $(p=0.0060)$, miscellaneous meat $(p=0.0089)$, total beef 
TABLE 33

T-TEST DETERMINATION ON CONSUMPTION OF MEAT BY NUTRITION AWARENESS: IMPORTANCE OR CONCERN FOR VARIETY

\begin{tabular}{lcccccc}
\hline & Yes & $(\mathrm{N}=231)$ & & No & $(\mathrm{N}=25)$ & \\
\cline { 2 - 5 } Meat Group & Mean & $\mathrm{SD}$ & & Mean & SD & P-Value \\
\hline Fish & 0.0556 & 0.0873 & 0.0373 & 0.0250 & 0.0178 \\
Total seafood & 0.0908 & 0.1122 & 0.0618 & 0.0449 & 0.0150 \\
\hline
\end{tabular}

TABLE 34

T-TEST DETERMINATION ON CONSUMPTION OF MEAT BY NUTRITION AWARENESS: IMPORTANCE OR CONCERN FOR PACKAGING

\begin{tabular}{lcccccc}
\hline & Yes & $(\mathrm{N}=117)$ & & No & $(\mathrm{N}=139)$ & \\
\cline { 2 - 5 } Meat Group & Mean & SD & & Mean & SD & P-Value \\
\hline Cubed Beef & 0.0497 & 0.0430 & 0.0608 & 0.0904 & 0.0001 \\
Other Beef & 0.0814 & 0.0575 & 0.0783 & 0.0470 & 0.0231 \\
Fish & 0.0496 & 0.0639 & 0.0582 & 0.0974 & 0.0001 \\
\hline
\end{tabular}


$(p=0.0114)$, and total pork $(p=0.0101)$ were least likely to be concerned with additives and preservatives (Table 35). Those respondents who were concerned with irradiation consumed more fish $(p=0.0344)$, seafood $(p=0.0197)$ and total seafood $(p=0.0161)$. Only respondents consuming more other beef $(p=0.0397)$ and ham $(p=0.0009)$ were least likely to be concerned with preservation by irradiation (Table 36 ). Importance or concern for residue was expressed by students eating more $f$ ish $(p=0.0033)$, and total seafood $(p=0.0029)$, whereas, respondents consuming more other beef $(p=0.0424)$ were not as concerned with residue (Table 37 ). Hormones in meat were considered important or a concern for those consuming more beef strips $(p=0.0231)$ and total seafood $(p=0.0415)$, while those consuming more other beef $(p=0.0363)$, and miscellaneous meat $(p=0.0295)$ were not (Table 38). Students who consumed more total seafood $(p=0.0001)$ indicated the importance or concern for bioengineered foods while those consuming more other beef $(p=0.0224)$, pork $(p=0.0401)$, and ham $(p=0.0258)$ did not (Table 39). It appears from these results that students need to be educated about the benefits and drawbacks with the use of additives and preservatives, irradiation, residue, hormones, and bioengineered foods. Students in this study may not be familiar with these contemporary food science terms therefore, their concerns may be unfounded. 
TABLE 35

T-TEST DETERMINATION ON CONSUMPTION OF MEAT BY NUTRITION AWARENESS: IMPORTANCE OR CONCERN FOR ADDITIVES AND PRESERVATIVES

\begin{tabular}{lccccc}
\hline & Yes & $N=93)$ & No & $(N=162)$ & \\
\cline { 2 - 5 } Meat Group & Mean & SD & Mean & SD & P-Value \\
\hline Ground Beef & 0.1601 & 0.1295 & 0.1983 & 0.0991 & 0.0105 \\
Other Beef & 0.0666 & 0.0513 & 0.0900 & 0.0507 & 0.0004 \\
Pork & 0.0810 & 0.0622 & 0.1023 & 0.0591 & 0.0060 \\
Turkey & 0.0704 & 0.0688 & 0.0500 & 0.0443 & 0.0251 \\
Seafood & 0.0120 & 0.0299 & 0.0060 & 0.1207 & 0.0440 \\
Miscellaneous & 0.0708 & 0.0604 & 0.0915 & 0.0644 & 0.0089 \\
Total Beef & 0.3723 & 0.1615 & 0.4183 & 0.1139 & 0.0114 \\
Total Pork & 0.1355 & 0.0884 & 0.1625 & 0.0734 & 0.0101 \\
Poultry & 0.2970 & 0.1685 & 0.2540 & 0.1224 & 0.0249 \\
Total Seafood & 0.1067 & 0.1438 & 0.0737 & 0.0651 & 0.0258 \\
& & & & & \\
\hline
\end{tabular}


TABLE 36

T-TEST DETERMINATION ON CONSUMPTION OF MEAT BY NUTRITION AWARENESS: IMPORTANCE OR CONCERN FOR PRESERVATION BY IRRADIATION

\begin{tabular}{lcccccc}
\hline & Yes & $(\mathrm{N}=93)$ & & No & $(\mathrm{N}=162)$ & \\
\cline { 2 - 5 } Meat Group & Mean & SD & & Mean & SD & P-Value \\
\hline Other Beef & 0.0713 & 0.0456 & 0.0845 & 0.0550 & 0.0397 \\
Ham & 0.0457 & 0.0400 & 0.0641 & 0.0466 & 0.0009 \\
Fish & 0.0720 & 0.1249 & 0.0434 & 0.0424 & 0.0344 \\
Seafood & 0.0139 & 0.0329 & 0.0056 & 0.0107 & 0.0197 \\
Total Seafood & 0.1145 & 0.1586 & 0.0728 & 0.0584 & 0.0161
\end{tabular}

TABLE 37

T-TEST DETERMINATION ON CONSUMPTION OF MEAT BY NUTRITION AWARENESS: IMPORTANCE OR CONCERN FOR RESIDUE

\begin{tabular}{|c|c|c|c|c|c|}
\hline \multirow[b]{2}{*}{ Meat Group } & \multicolumn{2}{|c|}{ Yes $(N=167)$} & \multicolumn{2}{|r|}{$(N=88)$} & \multirow[b]{2}{*}{ P-Value } \\
\hline & Mean & $\mathrm{SD}$ & Mean & $\mathrm{SD}$ & \\
\hline other Beef & 0.0745 & 0.0431 & 0.0901 & 0.0645 & 0.0424 \\
\hline Fish & 0.0628 & 0.0988 & 0.0374 & 0.0360 & 0.0033 \\
\hline Total seafood & 0.1004 & 0.1240 & 0.0654 & 0.0619 & 0.0029 \\
\hline
\end{tabular}


TABLE 38

T-TEST DETERMINATION ON CONSUMPTION OF MEAT BY NUTRITION AWARENESS: IMPORTANCE OR CONCERN FOR HORMONES IN MEAT

\begin{tabular}{lcccccc}
\hline & Yes & $(\mathrm{N}=103)$ & & No & $(\mathrm{N}=149)$ & \\
\cline { 2 - 5 } Meat Group & Mean & $\mathrm{SD}$ & & Mean & SD & P-Value \\
\hline Beef Strips & 0.0901 & 0.0488 & 0.0756 & 0.0506 & 0.0231 \\
Other Beef & 0.0718 & 0.0452 & 0.8527 & 0.0562 & 0.0363 \\
Miscellaneous & 0.0718 & 0.0517 & 0.0885 & 0.0693 & 0.0295 \\
Total Seafood & 0.1078 & 0.1484 & 0.0757 & 0.0656 & 0.0415 \\
\hline
\end{tabular}

TABLE 39

T-TEST DETERMINATION ON CONSUMPTION OF MEAT BY NUTRITION AWARENESS: IMPORTANCE OR CONCERN FOR BIOENGINEERED FOODS

\begin{tabular}{lcccccc}
\hline & Yes & $(N=102)$ & & No & $(N=151)$ & \\
\cline { 2 - 5 } Meat Group & Mean & SD & & Mean & SD & P-Value \\
\hline Other Beef & 0.0713 & 0.0453 & 0.0849 & 0.0561 & 0.0347 \\
Pork & 0.0834 & 0.0607 & 0.0995 & 0.0612 & 0.0401 \\
Ham & 0.0504 & 0.0423 & 0.0629 & 0.0476 & 0.0258 \\
Total Seafood & 0.1030 & 0.1485 & 0.0775 & 0.0676 & 0.0001 \\
\hline
\end{tabular}


Meat Consumption by Recommended

Servings of Meat

The analysis of variance (ANOVA) on the variables meat consumption and recommended servings of meat indicated a significant association as follows: cubed beef $(p=0.0361)$, beef strips $(p=0.0267)$, other beef $(p=0.0017)$, pork $(p=0.0047)$, fish $(p=0.0001)$, seafood $(p=0.0004)$ and total seafood $(p=0.0001)$ (Tables $40,42,44,46,48,50,52,54)$. For cubed beef and beef strips, those who answered from one to five servings ate more than those answering zero servings (Tables 41,43 ). For other beef, those who answered five servings ate the most than those who answered zero, one or four servings. Students who gave one of four servings also ate more than those who gave zero servings as an answer (Table 45). Students who gave three, four or one servings as their answer significantly ate more pork and total pork than those who answered zero as the recommended daily requirement. Those who answered five servings did not differ in their pork and total pork consumption from the other groups (Tables 47,49 ).

students in this study considered fish, seafood and total seafood as non-meat according to the ANOVA and Duncan's Multiple Range Test determinations. Those who gave zero as the recommended number of daily servings ate more fish, seafood, and total seafood. The reverse is true for 
TABLE 40

ANALYSIS OF VARIANCE (ANOVA) RESULTS FOR CUBED BEEF CONSUMPTION AND NUTRITION AWARENESS: RECOMMENDED SERVINGS OF MEAT

\begin{tabular}{lrccc}
\hline Source & df & Mean Square & $F$ & $P$ \\
\hline Servings & 5 & 0.0043 & 2.42 & 0.0361 \\
Error & 248 & 0.0018 & & \\
Total & 253 & & & \\
\end{tabular}

TABLE 41

DUNCAN'S MULTIPLE RANGE TEST FOR NUTRITION AWARENESS: RECOMMENDED SERVINGS OF MEAT AND

CUBED BEEF CONSUMPTION

\begin{tabular}{crcc}
\hline Servings of Meat & N & Mean & Grouping* \\
\hline 1 & 42 & 0.065 & A \\
4 & 10 & 0.063 & A \\
2 & 137 & 0.051 & A \\
5 & 5 & 0.050 & A \\
3 & 54 & 0.050 & A \\
0 & 6 & 0.006 & B
\end{tabular}

*Means with the same letter are not significantly different at the 0.05 level 
TABLE 42

ANALYSIS OF VARIANCE (ANOVA) RESULTS FOR BEEF STRIP CONSUMPTION AND NUTRITION AWARENESS: RECOMMENDED SERVINGS OF MEAT

\begin{tabular}{lcccc}
\hline Source & df & Mean Square & F & P \\
\hline Servings & 5 & 0.0063 & 2.58 & 0.0267 \\
Error & 248 & 0.0024 & & \\
Total & 253 & & & \\
\hline
\end{tabular}

TABLE 43

DUNCAN'S MULTIPLE RANGE TEST FOR NUTRITION AWARENESS: RECOMMENDED SERVINGS OF MEAT AND

BEEF STRIP CONSUMPTION

\begin{tabular}{cccc}
\hline Servings of Meat & $\mathrm{N}$ & Mean & Grouping* \\
\hline 5 & 5 & 0.106 & $\mathrm{~A}$ \\
3 & 54 & 0.090 & $\mathrm{~A}$ \\
4 & 10 & 0.085 & $\mathrm{~A}$ \\
2 & 137 & 0.080 & $\mathrm{~A}$ \\
1 & 42 & 0.077 & $\mathrm{~B}$ \\
0 & 6 & 0.018 & \\
\hline $\begin{array}{c}\text { *Means with the same letter are not significantly different } \\
\text { at the } 0.05 \text { level }\end{array}$ &
\end{tabular}


TABLE 44

ANALYSIS OF VARIANCE (ANOVA) RESULTS FOR OTHER BEEF CONSUMPTION AND NUTRITION AWARENESS: RECOMMENDED SERVINGS OF MEAT

\begin{tabular}{lcccc}
\hline Source & df & Mean Square & F & P \\
\hline Servings & 5 & 0.0504 & 3.98 & 0.0017 \\
Error & 248 & 0.6279 & & \\
Total & 253 & & & \\
\end{tabular}

TABLE 45

DUNCAN'S MULTIPLE RANGE TEST FOR NUTRITION AWARENESS: RECOMMENDED SERVINGS OF MEAT AND

OTHER BEEF CONSUMPTION

\begin{tabular}{cccc}
\hline Servings of Meat & $\mathrm{N}$ & Mean & Grouping* \\
\hline 5 & 5 & 0.115 & $\mathrm{AB}$ \\
3 & 54 & 0.095 & $\mathrm{AB}$ \\
2 & 137 & 0.081 & $\mathrm{~B}$ \\
1 & 42 & 0.068 & $\mathrm{~B}$ \\
4 & 10 & 0.066 & $\mathrm{C}$ \\
0 & 6 & 0.016 & \\
\hline $\begin{array}{c}\text { * Means with the same letter are not significantly different } \\
\text { at the } 0.05 \text { level }\end{array}$ &
\end{tabular}


TABLE 46

ANALYSIS OF VARIANCE (ANOVA) RESULTS FOR PORK CONSUMPTION AND NUTRITION AWARENESS:

RECOMMENDED SERVINGS OF MEAT

\begin{tabular}{lcccc}
\hline Source & df & Mean Square & F & P \\
\hline Servings & 5 & 0.0098 & 2.76 & 0.0192 \\
Error & 248 & 0.0036 & & \\
Total & 253 & & & \\
\end{tabular}

TABLE 47

DUNCAN'S MULTIPLE RANGE TEST FOR NUTRITION AWARENESS:

RECOMMENDED SERVINGS OF MEAT AND

PORK CONSUMPTION

\begin{tabular}{cccc}
\hline Servings of Meat & $\mathrm{N}$ & Mean & Grouping* \\
\hline 3 & 54 & 0.112 & $\mathrm{~A}$ \\
4 & 10 & 0.102 & $\mathrm{~A}$ \\
1 & 42 & 0.100 & $\mathrm{~A}$ \\
2 & 137 & 0.088 & $\mathrm{~A}$ \\
5 & 5 & 0.077 & $\mathrm{AB}$ \\
0 & 6 & 0.032 & $\mathrm{~B}$
\end{tabular}

*Means with the same letter are not significantly different at the 0.05 level 
TABLE 48

ANALYSIS OF VARIANCE (ANOVA) RESULTS FOR TOTAL PORK CONSUMPTION AND NUTRITION AWARENESS:

RECOMMENDED SERVINGS OF MEAT

\begin{tabular}{lcccc}
\hline Source & df & Mean Square & $F$ & $P$ \\
\hline Servings & 5 & 0.0212 & 3.47 & 0.0047 \\
Error & 248 & 0.0061 & & \\
Total & 253 & & & \\
\end{tabular}

TABLE 49

DUNCAN'S MULTIPLE RANGE TEST FOR NUTRITION AWARENESS:

RECOMMENDED SERVINGS OF MEAT AND

TOTAL PORK CONSUMPTION

\begin{tabular}{cccc}
\hline Servings of Meat & N & Mean & Grouping* \\
\hline 3 & 54 & 0.181 & $\mathrm{~A}$ \\
1 & 42 & 0.159 & $\mathrm{~A}$ \\
4 & 10 & 0.144 & $\mathrm{~A}$ \\
2 & 137 & 0.144 & $\mathrm{AB}$ \\
5 & 5 & 0.117 & $\mathrm{~B}$ \\
0 & 6 & 0.067 & \\
\hline $\begin{array}{c}\text { * Means with the same letter are not significantly different } \\
\text { at the } 0.05 \text { level }\end{array}$ &
\end{tabular}


TABLE 50

ANALYSIS OF VARIANCE (ANOVA) RESULTS FOR TOTAL

FISH CONSUMPTION AND NUTRITION AWARENESS:

RECOMMENDED SERVINGS OF MEAT

\begin{tabular}{lcccc}
\hline Source & df & Mean Square & $F$ & $P$ \\
\hline Servings & 5 & 0.0827 & 15.43 & 0.0001 \\
Error & 248 & 0.0054 & & \\
Total & 253 & & & \\
\end{tabular}

TABLE 51

DUNCAN'S MULTIPLE RANGE TEST FOR NUTRITION AWARENESS: RECOMMENDED SERVINGS OF MEAT AND

FISH CONSUMPTION

\begin{tabular}{cccc}
\hline Servings of Meat & $\mathrm{N}$ & Mean & Grouping* \\
\hline 0 & 6 & 0.309 & $\mathrm{~A}$ \\
2 & 137 & 0.053 & $\mathrm{~B}$ \\
1 & 42 & 0.046 & $\mathrm{~B}$ \\
4 & 10 & 0.039 & $\mathrm{~B}$ \\
3 & 54 & 0.037 & $\mathrm{~B}$ \\
5 & 5 & 0.030 & \\
\hline $\begin{array}{c}\text { *Means with the same letter are not significantly different } \\
\text { at the } 0.05 \text { level }\end{array}$ &
\end{tabular}


TABLE 52

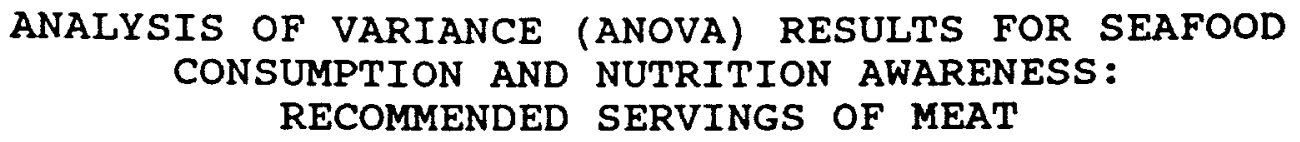

\begin{tabular}{lcccc}
\hline Source & df & Mean Square & F & P \\
\hline Servings & 5 & 0.0021 & 4.65 & 0.0004 \\
Error & 248 & 0.0004 & & \\
Total & 253 & & & \\
\hline
\end{tabular}

TABLE 53

DUNCAN'S MULTIPLE RANGE TEST FOR NUTRITION AWARENESS: RECOMMENDED SERVINGS OF MEAT AND

SEAFOOD CONSUMPTION

\begin{tabular}{cccc}
\hline Servings of Meat & N & Mean & Grouping* \\
\hline 0 & 6 & 0.048 & A \\
1 & 42 & 0.011 & B \\
5 & 5 & 0.007 & B \\
2 & 137 & 0.007 & B \\
3 & 54 & 0.006 & B \\
4 & 10 & 0.005 & \\
\hline $\begin{array}{c}\text { *Means with the same letter are not significantly different } \\
\text { at the } 0.05 \text { level }\end{array}$ &
\end{tabular}


TABLE 54

ANALYSIS OF VARIANCE (ANOVA) RESULTS FOR TOTAL SEAFOOD CONSUMPTION AND NUTRITION AWARENESS:

RECOMMENDED SERVINGS OF MEAT

\begin{tabular}{lcccc}
\hline Source & df & Mean Square & F & P \\
\hline Servings & 5 & 0.1282 & 14.31 & 0.0001 \\
Error & 248 & 0.0090 & & \\
Total & 253 & & & \\
\end{tabular}

TABLE 55

DUNCAN'S MULTIPLE RANGE TEST FOR NUTRITION AWARENESS: RECOMMENDED SERVINGS OF MEAT AND TOTAL SEAFOOD CONSUMPTION

\begin{tabular}{cccc}
\hline Servings of Meat & $\mathrm{N}$ & Mean & Grouping* \\
\hline 0 & 6 & 0.408 & A \\
2 & 137 & 0.084 & B \\
1 & 42 & 0.080 & B \\
3 & 54 & 0.071 & B \\
4 & 10 & 0.070 & B \\
5 & 5 & 0.063 & \\
\hline $\begin{array}{l}\text { * Means with the same letter are not significantly different } \\
\text { at the } 0.05 \text { level }\end{array}$ &
\end{tabular}


83

those who answered one to five servings of meat as the daily requirement (Tables 51, 53, 55). Possibly those who answered zero may have a misconception that meat is unhealthy therefore, they chose meats which were generally thought of as being lowfat content.

Based on these results reported in Tables 16 through 55, indicating associations between meat consumption and the nutrition awareness variables, the researcher rejected $\mathrm{Ho}_{3}$. If other nutrition awareness variables such as food consumption related to stress situation are considered, then the researcher failed to reject $\mathrm{Ho}_{3}$. 
CHAPTER V

\section{SUMMARY AND RECOMMENDATIONS}

The purpose of this research was to determine the nutrition awareness and meat consumption of college students. Three hypotheses were postulated to determine if the college students' consumption of meat were effected by demographic variables and their nutrition awareness.

The results of the data collected from the questionnaires completed by the students are presented in Chapter IV. The sample population was randomly chosen from students living in the residence halls at Oklahoma state University. Data obtained from the 257 questionnaires were analyzed using frequencies, percentages, student's t-tests, ANOVA and Duncan's Multiple Range Tests.

The majority of the respondents were freshman, white, females between the ages of 17 and 22 in the college of Arts and sciences (Table 1). Over 30 percent of the students reported missing breakfast every day, while about 40 percent ate lunch and dinner five to seven times a week (Figure 1). The majority of the students had knowledge of the Food Guide Pyramid (Table 3).

Female students perceived the importance of limiting sugar, fat, highly processed foods, alcoholic beverages, 
carbonated beverages, and snack foods more so than the males (Figure 2). In addition, the females were more concerned with food labels; diet, health and nutrition; nutritional value; caloric content and appearance and condition of the foods they consume (Figure 3). Males consumed more meat in general, specifically beef and pork, while the females consumed more chicken and turkey. Students who were concerned about nutrition, health, and wellness selected meats which reflected these concerns.

\section{Recommendations}

The research instrument was lengthy and covered broad topics. Future researchers may wish to divide the study into two surveys: (1) to discover nutrition awareness and (2) to determine meat consumption. A second mailing may also increase the response rate. The time of year the questionnaire was distributed might have had an effect on the response rate. Perhaps the study should have been conducted in the fall semester because there are more students in the residence halls at that time. Also, students may not be involved in many activities at the start of the academic year, therefore they may be more apt to participate in a research study.

Additional research needs to be conducted to determine why males differed from females in response to nutrition awareness. Other studies should be conducted on possible solutions to increase nutrition awareness of young adults. 


\section{Implications}

Skipping breakfast appeared to be evident among college students. Nutrition educators need to identify barriers contributing to meals missed by young adults and focus on the importance of eating three balanced and nutritious meals a day. Multi-media presentations utilizing TV, MTV, radio and print promoting the benefits of good nutrition and consumption of meat in the appropriate amounts to promote optimum health is crucial.

Female students in this study were more aware and concerned about the benefits of diet, health and nutrition than males. Females also consumed more chicken and turkey while males preferred beef and pork.

Programs promoting the benefits of good nutrition and consumption of meat and protein rich foods should be developed and presented utilizing TV, MTV, radio and print media to reach young adults. These materials should also be made available to college students via newsletters, bulletin boards, table tents, and letters to parents. 


\section{REFERENCES}

Adolf, M. M. (1987, January). Beef: A food that fits. School Foodservice Journal, $41(1), 73$.

American Meat Institute. (1985). Fat Facts. Washington, DC: Author.

Best, J. W. Research in Education. (1981). Englewood cliffs, NJ: Prentice-Hall.

Borchett, H. R. (1988, April). Animal products in American diets. News Report, $38(4), 2-6$. Washington, DC: National Academy of sciences, National Research council.

Breidenstein, B. (1987, March/April). Nutrient value of meat. Food and Nutrition News, 59(2), 43-55.

Chery, A., Sabry, J. H., \& Woolcott, D.M. (1987). Nutrition knowledge and misconceptions of university students: 1971 vs. 1984. Journal of Nutrition Education, 19(5), 237-241.

Chou, M. (1983, August). Consumer consumption of protein foods. Cereal Foods World, 28(8), 465.

Claudio, V. S., \& Lagua, R. T. (1991). Nutrition and Diet Therapy Dictionary. New York: Van Nostrand Reinhold.

Craven, J., Huans, K., \& Haider, R. (1989, February).

U. S. demand for meat. National Food Review (NFR 20). Washington, DC: United States Department of Agriculture Economic Research Service.

Cypel, Y. S., \& Prather, E. S. (1993, March). Assessment of the food perceptions of university students. Journal of the American Dietetic Association, 93(3), $330-332$.

Environmental Nutrition Newsletter. (1979, May/June). Where's the meat? $\underline{2}(4), 1-2$. New York: Environmental Nutrition, Inc.

Freeland-Graves J. H., \& Peckaham, G. C. (1987). Foundations of Food Preparation. New York: MacMillan Publishing Company. 
Galloway, J. (1991). The Diet-health Issues of Beef Consumption and their Reflection on the Buying Behavior of Oklahoma Extension Homemakers. (Unpub. M. S. thesis, Oklahoma State University).

Guralnik, D. B. (1979). Webster's New World Dictionary. Cleveland, $\mathrm{OH}$ : William Collins Publishers.

Hanson, C. F. (1994). Nutrient adequacy of diets of young adult males vs females with and without animal products. Journal of FASEB, $\underline{8}$, A183.

Hernon, J. F., Skinner, J. D., Andrews, F. E., \& Penfield, M. P. (1896, February). Nutrient intakes and foods selected by college students: Comparisons among subgroups divided by energy intake. Journal of the American Dietetic Association, 86 (2), 217-221.

Hertzler, A. A., \& Frary, R. B. (1989, Summer). Food behavior of college students. Adolescence, 24(94), 349-356.

Hopkins, L., \& Thomas, G. (1984, January/February). The nutritional aspects of animal protein consumption. Nutrition Today, $19(1), 6-9,11-14$.

Jerome, N. W., Kandel, R. F. \& Pelto, G. H. (1980). Nutritional Anthropology. Pleasantville, NY: Redgrave Publishing Company.

Khan, M. A., \& Lipke, L. D. (1982). Snacking and its contribution to food and nutrient intake of college students. Journal of the American Dietetic Association, 81(5), 583-587.

Kitler, P. G., \& Sucher, K. (1989). Food and culture in America. New York: Van Nostrand Reinhold.

Lieux, E. M. \& Manning, C. K. (1992, May). Evening meals selected by college students: Impact of the food service system. Journal of the American Dietetic Association, $92(5), 560-566$.

Marrale, J. C. , Shipman, J. H., \& Rhodes, M. L. (1986, January/February). What some college students eat. Nutrition today, 16-21.

Meat consumption Trends and Patterns: (1981). Consumption section, statistical and historical research branch, 1-8. Washington, DC: United States Department of Agriculture Economic Research Service. 
Moschini, G., \& Meilke, K. (1989, May). Modeling the pattern of structural change in U. S. meat demand. American Journal of Agricultural Economics, $71(2)$, 253-261.

Pariza, M. (1984, March). A perspective on diet, nutrition and cancer. Journal of the American Medical Association, 251(11), 1455-1458.

Plato, R. (1993). Attitudes, Knowledge, and Consumption of Fruits and Vegetables by college Students. (Unpub. M.S. thesis, oklahoma state University.)

Prescott, R. (1981) . Per capita food consumption highlights for 1981. Washington, DC: United states Department of Agriculture Economic Research Service. National Food Review, 20, pp. 11-12.

Ridgway, A. (1989). College students' snack food consumption behaviors and nutritional awareness. (Unpub. M.S. thesis, Oklahoma state University.)

SAS Institute Inc. (1979). SAS User's Guide. Cary, NC: SAS Institute.

Schank, M. J., Thomas, B., \& Young, M. (1987). Health behavioral changes among adult women attending a course in women's health. Family and Community Health, 10 (2), 66-71.

Steel, R. G. \& Torrie, J. H. (1980). Principles and procedures of Statistics: A Biometrical Approach. New York, NY: McGraw Hill.

Sweeten, M., Cross, H., Smith, G., Savell, J., \& Smith, S. (1990, January). Lean beef: Impetus for lipid modifications. Journal of the American Dietetic Association, 90(1), 87-92.

Thomas, P. R. (Ed.) . (1991). Improving America's Diet and Health: From Recommendations to Action. Washington, DC: Committee on Dietary Guidelines Implementation, Food and Nutrition Board, Institute of Medicine, National Academy Press, 90-93.

U. S. Department of Health and Human Services. (1993). Nutrition Monitoring in the United States. Washington, DC: U. S. Department of Health and Human Services (PHS) Publication 93-1255-2. 
Wyse, B., Hansen, R., Windham, C., \& Wittwer, C. (1986, Spring). The status of human nutrition and agricultural productivity. Journal of Home Economics, 78(1), 19-24. 
APPENDIXES 
APPENDIX A

COVER LETTER AND QUESTIONNAIRE 


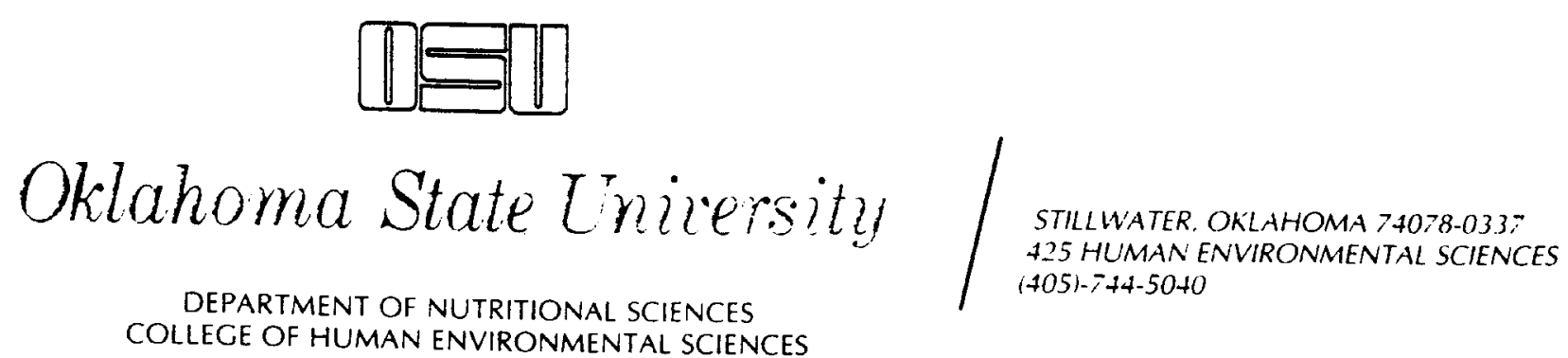

March 14, 1994

Dear Student:

Congratulations! You have been selected to participate in a very important study entitled "Meat Consumption of College Students." College students make up a large segment of our nation's population, however, there have been very few studies to determine what college students actually eat.

Please take 10 minutes of your time to complete the questionnaire provided. Your cooperation and paticipation are very much appreciated. A summary of results will be made available to the Department of Residential Life in Iba Hall.

In appreciation for taking part in this study, there will be a special Treat for you at the front desk. To receive the Treat turn in a completed questionnaire in the box provided near the Residential Life front desk by March 18. Again we thank you for your time and paticipation in this project. We will look forward to hearing from you soon.

Sincerely,

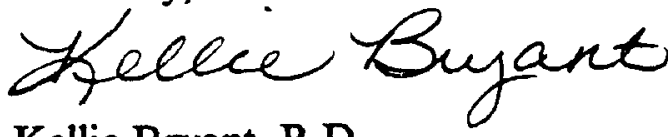

Kellie Bryant, R.D.

Graduate Student

Lea 2 sbro

Lea L. Ebro, Ph.D., R.D.

Major Advisor 


\section{Meat Consumption of College Students}

\section{GENERAL INFORMATION}

Please check or fill in the appropriate information concerning yourself.

1. Gender $\square$ Male $\quad$ Female

2. Race $\square$ White $\square$ Black $\square$ Native American

3. Age Group $\square$ 17-22 $\square 23-28 \quad \square 29-33 \quad \square$ over 33

4. Education Level $\square$ Freshman $\square$ Sophomore $\square$ Junior $\square$ Senior $\square$ Graduate $\square$ Special

5. College $\square$ Arts and Science $\square$ Business $\square$ Human Environmental Sciences $\square$ Agriculture $\quad \square$ Education $\square$ Veterinary Medicine $\square$ Engineering $\square$ Graduate $\square$ Special

6. Do you have a meal plan? $\square$ Yes $\square$ No If yes, state number of meals per week.

7. How many times per week do you eat Breakfast___ Lunch__ Dinner ___

8. A healthy diet will include eating how many servings of meat each day.

9. Is the choice of meat in your cafeteria a factor in your meat selection?

$\square$ Yes $\square$ No

10. Is cooking or preparation method a factor in your meat selection?
$\square$ Yes
$\square$ No

\section{NUTRITION AWARENESS INFORMATION}

11. For the following statements please check YES or NO as the statement that best indicates your response.

YES

NO

a. I try to limit eating foods high in:

1. sodium (salt)

2. sugar

3. cholesterol

4. fat

b. I try to limit highly processed foods (bologna, sausage, etc.).

c. I try to limit alcoholic beverages.

d. I try to limit carbonated beverages. 
e. I try to limit snack food (cookies, cake, pie, etc.)

f. The following statements are important to me or concern me.

1. food labels with nutrient information

2. diet, health and nutrition

3. nutritional value

4. caloric content

5. appearance and condition

6. taste and flavor

7. convenience

8. price

9. variety

10. vitamin and mineral content

11. additives and preservatives

12. preservation by irradiation

13. packaging (type and size)

14. residue (pesticide) in produce

15. hormones in meat

16. bioengineered foods

g. My consumption of food is related to my stress situation.

\section{CONSUMPTION}

For the following list of foods, please check the appropriate box to tell us how many times you consumed them since the beginning of the Spring semester.

\begin{tabular}{|l|c|c|c|c|c|l|}
\hline & $\begin{array}{c}\text { More } \\
\text { than } \\
\text { Once } \\
\text { per } \\
\text { Week }\end{array}$ & $\begin{array}{c}\text { Once } \\
\text { per } \\
\text { Week }\end{array}$ & $\begin{array}{c}\text { More } \\
\text { than } \\
\text { Once } \\
\text { per } \\
\text { Month }\end{array}$ & $\begin{array}{c}\text { Once } \\
\text { per } \\
\text { Month }\end{array}$ & Seldom & Never \\
\hline GROUND BEEF & XXXX & XXXX & XXXX & XXXX & XXXX & XXXX \\
\hline Sloppy Joes & & & & & & \\
\hline Spaghetti Sauce & & & & & & \\
\hline Hamburgers & & & & & & \\
\hline Meatloaf & & & & & & \\
\hline Meatballs & & & & & & \\
\hline
\end{tabular}




\begin{tabular}{|c|c|c|c|c|c|c|}
\hline GROUND BEEF CONTINUED & $\begin{array}{c}\text { More } \\
\text { than } \\
\text { Once } \\
\text { per } \\
\text { Week } \\
\end{array}$ & $\begin{array}{c}\text { Once } \\
\text { per } \\
\text { Week }\end{array}$ & $\begin{array}{c}\text { More } \\
\text { than } \\
\text { Once } \\
\text { per } \\
\text { Month } \\
\end{array}$ & $\begin{array}{c}\text { Once } \\
\text { per } \\
\text { Month }\end{array}$ & Seldom & Never \\
\hline \multicolumn{7}{|l|}{ Goulash } \\
\hline \multicolumn{7}{|l|}{ Tamale } \\
\hline \multicolumn{7}{|l|}{ Lasagna } \\
\hline \multicolumn{7}{|l|}{ Tacos/Taco Salad } \\
\hline \multicolumn{7}{|l|}{ Burritos } \\
\hline \multicolumn{7}{|l|}{ Enchiladas } \\
\hline \multicolumn{7}{|l|}{ Chili/Chili Pie } \\
\hline \multicolumn{7}{|l|}{ Other (specify) } \\
\hline CUBED MEAT (BEEF) & $\mathrm{XXXX}$ & $\mathbf{X X X X}$ & $\mathbf{X X X X}$ & XXXX & $\mathbf{X X X X}$ & $\mathbf{X X X X}$ \\
\hline \multicolumn{7}{|l|}{ Stew } \\
\hline \multicolumn{7}{|l|}{ Casserole } \\
\hline \multicolumn{7}{|l|}{ K-Bob } \\
\hline \multicolumn{7}{|l|}{ Stir Fry } \\
\hline \multicolumn{7}{|l|}{ Stroganoff } \\
\hline \multicolumn{7}{|l|}{ Braised w/ noodles or rice } \\
\hline \multicolumn{7}{|l|}{ Other (specify) } \\
\hline BEEF STRIPS/SLICED & $\mathbf{X X X X}$ & $\mathbf{X X X X}$ & XXXX & $\mathbf{X X X X}$ & $\mathbf{X X X X}$ & $\mathbf{X X X X}$ \\
\hline \multicolumn{7}{|l|}{ Fajita } \\
\hline \multicolumn{7}{|l|}{ Philly Beef } \\
\hline \multicolumn{7}{|l|}{ Hoagie } \\
\hline \multicolumn{7}{|l|}{ Barbecue } \\
\hline \multicolumn{7}{|l|}{ Chinese } \\
\hline \multicolumn{7}{|l|}{ Stir Fry } \\
\hline \multicolumn{7}{|l|}{ Italian Sub } \\
\hline \multicolumn{7}{|l|}{ French Dip } \\
\hline \multicolumn{7}{|l|}{ Other (specify) } \\
\hline OTHER BEEF ITEMS & XXXX & $\mathbf{X X X X}$ & $\mathbf{X X X X}$ & $\mathbf{X X X X}$ & $\mathbf{X X X X}$ & $\mathbf{X X X X}$ \\
\hline \multicolumn{7}{|l|}{ Fillet Steak (T-bone, sirloin, etc.) } \\
\hline Roast (pot-roast, chuck, etc.) & & & & & . & \\
\hline Chicken Fried Steak & & & & & & \\
\hline
\end{tabular}




\begin{tabular}{|c|c|c|c|c|c|c|}
\hline $\begin{array}{l}\text { OTHER BEEF ITEMS } \\
\text { CONTINUED }\end{array}$ & $\begin{array}{c}\text { More } \\
\text { than } \\
\text { Once } \\
\text { per } \\
\text { Week }\end{array}$ & $\begin{array}{c}\text { Once } \\
\text { per } \\
\text { Week }\end{array}$ & $\begin{array}{c}\text { More } \\
\text { than } \\
\text { Once } \\
\text { per } \\
\text { Month } \\
\end{array}$ & $\begin{array}{c}\text { Once } \\
\text { per } \\
\text { Month }\end{array}$ & Seldom & Never \\
\hline \multicolumn{7}{|l|}{ Ribs } \\
\hline \multicolumn{7}{|c|}{ Processed Beef (jerky, sausage, etc.) } \\
\hline \multicolumn{7}{|l|}{ Cutlet } \\
\hline \multicolumn{7}{|l|}{ Brisket } \\
\hline \multicolumn{7}{|l|}{ Other (specify) } \\
\hline PORK & $\mathbf{X X X X}$ & $\mathbf{X X X X}$ & XXXX & $\mathbf{X X X X}$ & $\mathbf{X X X X}$ & $\mathbf{X X X X}$ \\
\hline \multicolumn{7}{|l|}{ Roast (loin) } \\
\hline \multicolumn{7}{|l|}{ Chops } \\
\hline \multicolumn{7}{|l|}{ Stir Fry } \\
\hline \multicolumn{7}{|l|}{ Pot Pie } \\
\hline \multicolumn{7}{|l|}{ Cutlet } \\
\hline \multicolumn{7}{|l|}{ Tenderloin/Fillet } \\
\hline \multicolumn{7}{|l|}{ Casserole } \\
\hline \multicolumn{7}{|l|}{ Egg rolls } \\
\hline \multicolumn{7}{|l|}{ Bacon } \\
\hline \multicolumn{7}{|l|}{ Canadian Bacon } \\
\hline \multicolumn{7}{|l|}{ Sausage, (patty, link) } \\
\hline \multicolumn{7}{|l|}{ Chinese } \\
\hline \multicolumn{7}{|l|}{ Ribs } \\
\hline \multicolumn{7}{|l|}{ Other (specify) } \\
\hline HAM & $\mathbf{X X X X}$ & $\mathrm{XXXX}$ & $\mathbf{X X X X}$ & $\mathbf{X X X X}$ & $\mathbf{X X X X}$ & $\mathbf{X X X X}$ \\
\hline \multicolumn{7}{|l|}{ Carved/Baked } \\
\hline \multicolumn{7}{|l|}{ Sandwich Slices } \\
\hline \multicolumn{7}{|c|}{ Casseroles ( $w /$ beans, potatoes, etc.) } \\
\hline \multicolumn{7}{|l|}{ Steak } \\
\hline \multicolumn{7}{|c|}{ Ham and Turkey Cordon Bleu } \\
\hline \multicolumn{7}{|c|}{ Other (specify) } \\
\hline CHICKEN & $\mathbf{X X X X}$ & XXXX & XXXX & $\mathbf{X X X X}$ & $\mathbf{X X X X}$ & XXXX \\
\hline \multicolumn{7}{|l|}{ Fried } \\
\hline Baked & & & & & & \\
\hline
\end{tabular}




\begin{tabular}{|c|c|c|c|c|c|c|}
\hline CHICKEN CONTINUED & $\begin{array}{l}\text { More } \\
\text { than } \\
\text { Once } \\
\text { per } \\
\text { Week }\end{array}$ & $\begin{array}{c}\text { Once } \\
\text { per } \\
\text { Week }\end{array}$ & $\begin{array}{c}\text { More } \\
\text { than } \\
\text { Once } \\
\text { per } \\
\text { Month } \\
\end{array}$ & $\begin{array}{c}\text { Once } \\
\text { per } \\
\text { Month }\end{array}$ & Seldom & Never \\
\hline \multicolumn{7}{|l|}{ Grilled } \\
\hline \multicolumn{7}{|l|}{ Stir Fry } \\
\hline \multicolumn{7}{|l|}{ Patty } \\
\hline \multicolumn{7}{|l|}{ Nuggets } \\
\hline \multicolumn{7}{|l|}{ Buffalo Wings } \\
\hline \multicolumn{7}{|l|}{ Stuffed (Kiev, cordon bleu, etc.) } \\
\hline \multicolumn{7}{|l|}{ Casseroles, Pot Pie } \\
\hline \multicolumn{7}{|l|}{ Chicken (w/ noodles, rice, etc.) } \\
\hline \multicolumn{7}{|l|}{ Breast Fillet } \\
\hline \multicolumn{7}{|l|}{ Chicken (in Chinese food) } \\
\hline \multicolumn{7}{|l|}{ Chicken (in Mexican food) } \\
\hline \multicolumn{7}{|l|}{ Other (specify) } \\
\hline TURKEY & $\mathbf{X X X X}$ & $\mathbf{X X X X}$ & $\mathbf{X X X X}$ & $\mathbf{X X X X}$ & $\mathbf{X X X X}$ & $\mathbf{X X X X}$ \\
\hline \multicolumn{7}{|l|}{ Roast (sliced \&/or with dressing) } \\
\hline \multicolumn{7}{|l|}{ Sandwich } \\
\hline \multicolumn{7}{|l|}{ Casserole } \\
\hline \multicolumn{7}{|l|}{ Turkey Tetrazzini } \\
\hline \multicolumn{7}{|l|}{ Turkey Divan } \\
\hline \multicolumn{7}{|l|}{ Turkey Steak } \\
\hline \multicolumn{7}{|l|}{ Other (specify) } \\
\hline FISH, COD, CATFISH, ETC. & $\mathbf{X X X X}$ & $\mathbf{X X X X}$ & $\mathbf{X X X X}$ & $\mathbf{X X X X}$ & $\mathbf{X X X X}$ & XXXX \\
\hline \multicolumn{7}{|l|}{ Fried } \\
\hline \multicolumn{7}{|l|}{ Baked } \\
\hline \multicolumn{7}{|l|}{ Stuffed } \\
\hline \multicolumn{7}{|l|}{ Broiled/Braised } \\
\hline \multicolumn{7}{|l|}{ Sticks/Nuggets } \\
\hline \multicolumn{7}{|l|}{ Tuna } \\
\hline \multicolumn{7}{|l|}{ Salmon } \\
\hline Other (specify) & & & & & & \\
\hline
\end{tabular}




\begin{tabular}{|c|c|c|c|c|c|c|}
\hline & $\begin{array}{l}\text { More } \\
\text { than } \\
\text { Once } \\
\text { per } \\
\text { Week }\end{array}$ & $\begin{array}{c}\text { Once } \\
\text { per } \\
\text { Week }\end{array}$ & $\begin{array}{c}\text { More } \\
\text { than } \\
\text { Once } \\
\text { per } \\
\text { Month }\end{array}$ & $\begin{array}{l}\text { Once } \\
\text { per } \\
\text { Month }\end{array}$ & Seldom & Never \\
\hline SHRIMP & $\mathbf{X X X X}$ & $\mathbf{X X X X}$ & $\mathbf{X X X X}$ & $\mathbf{X X X X}$ & $\mathbf{X X X X}$ & $\mathbf{X X X X}$ \\
\hline \multicolumn{7}{|l|}{ Fried } \\
\hline \multicolumn{7}{|l|}{ Boiled } \\
\hline \multicolumn{7}{|l|}{ Broiled/Braised } \\
\hline \multicolumn{7}{|l|}{ Stuffed } \\
\hline \multicolumn{7}{|l|}{ Shrimp (w/ rice) } \\
\hline \multicolumn{7}{|l|}{ Casserole } \\
\hline \multicolumn{7}{|l|}{ Other (specify) } \\
\hline OTHER SEAFOOD & $\mathbf{X X X X}$ & $\mathbf{X X X X}$ & $\mathbf{X X X X}$ & XXXX & XXXX & XXXX \\
\hline \multicolumn{7}{|l|}{ Lobster } \\
\hline \multicolumn{7}{|l|}{ Scallops } \\
\hline \multicolumn{7}{|l|}{ Crab } \\
\hline \multicolumn{7}{|l|}{ Other (specify) } \\
\hline MISCELLANEOUS & $\mathbf{X X X X}$ & $\mathbf{X X X X}$ & $\mathbf{X X X X}$ & $\mathbf{X X X X}$ & $\mathbf{X X X X}$ & $\mathbf{X X X X}$ \\
\hline \multicolumn{7}{|l|}{ Hot Dogs } \\
\hline \multicolumn{7}{|l|}{ Corn Dogs } \\
\hline \multicolumn{7}{|l|}{ Veal } \\
\hline \multicolumn{7}{|l|}{ Lamb } \\
\hline \multicolumn{7}{|c|}{ Organ Meats (liver, fries, etc.) } \\
\hline \multicolumn{7}{|l|}{ Wild Game } \\
\hline \multicolumn{7}{|l|}{ Pizza (w/ meat) } \\
\hline \multicolumn{7}{|l|}{ Gyro } \\
\hline Other (specify) & & & & & & \\
\hline
\end{tabular}

\section{Thank you for your time.}

Now, go to the front desk to receive your special treat! 
APPENDIX B

FOOD GUIDE PYRAMID 
APPENDIX $C$

RECOMMENDED DIETARY GUIDELINES 
Nutrition and Your Health:

\section{Dietary Guidelines for Americans}

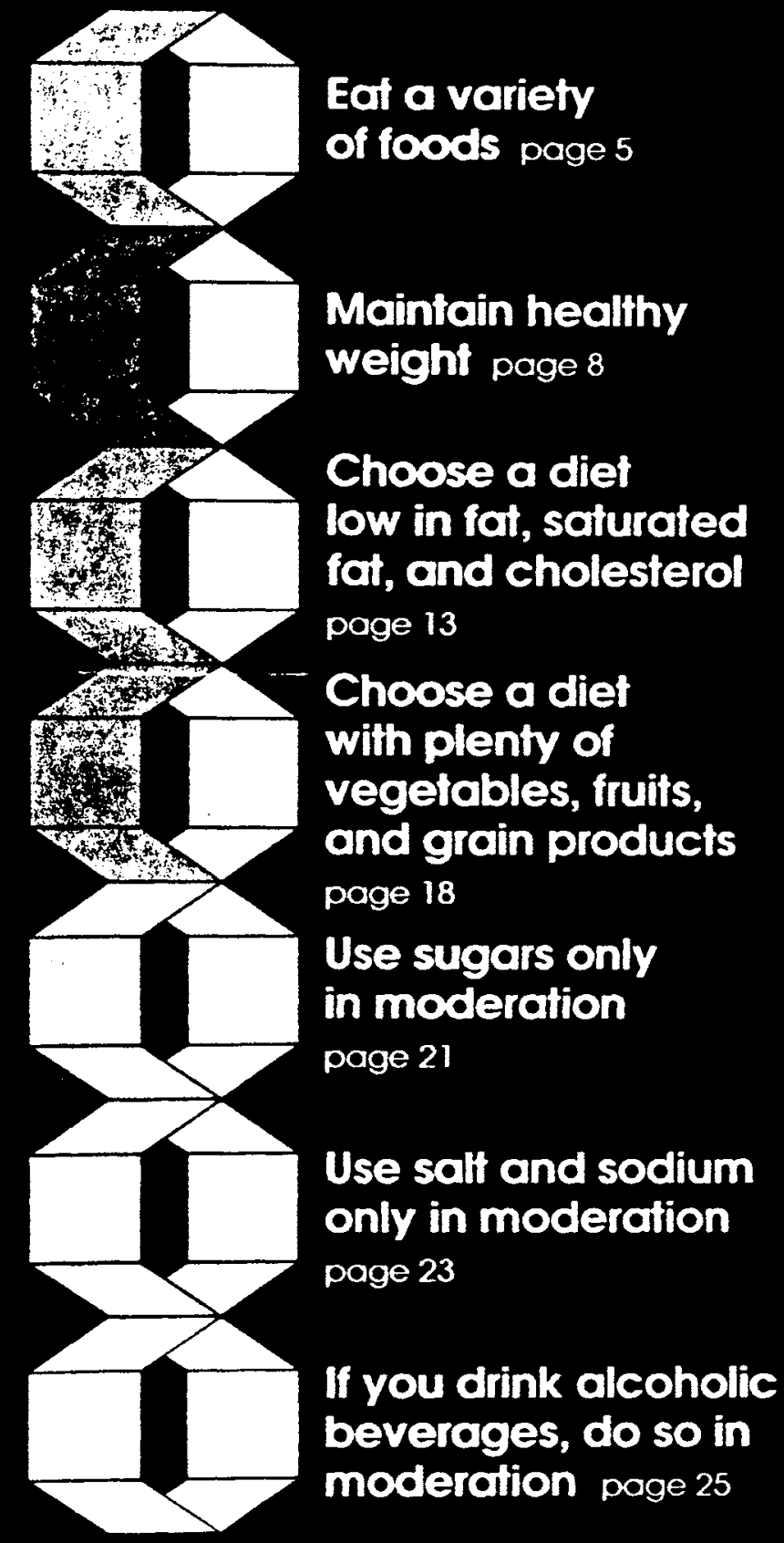

Third Edition. 1990

U.S. Department of Agriculture

U.S. Department of Health and Human Services 
APPENDIX D

\section{CHI-SQUARE FREQUENCY ANALYSIS TABLES \\ FOR THOSE ASSOCIATIONS WHICH \\ WERE SIGNIFICANT}


Key to Tables

In the following tables, the abbreviations used refer to questions on the questionnaire.

Q1 refers to sender

$1=$ male, 2 = female

Q4 refers to education level

1 = Freshman

2 = Sophomore,

3 = Junior

$4=$ Senior

5 = Graduate

$6=$ Special

Q5 refers to college

$1=$ Arts and science

2 = Business,

$3=$ Human Environmental Sciences

4 = Agriculture

5 = Education

6 = Veterinary Medicine,

7 = Engineering

8 = Graduate

9 = Special

88 refers to a healthy diet: will include eating how many servings of meat each day

$$
\begin{aligned}
& 0=0 \\
& 1=1 \\
& 2=2 \\
& 3=3 \\
& 4=4 \\
& 5=5 \text { or more }
\end{aligned}
$$

Q11A-2 refers to I try to limit foods high in sugar $1=$ Yes $2=$ No

Q11A.4 refers to I try to limit foods high in fat $1=$ Yes 2 = No

Q11.B refers to I try to limit highly processed foods 1 = Yes 2 = No

Q11.C refers to I try to limit alcoholic beverages 1 = Yes 2 = No

Q11.D refers to I try to limit carbonated beverages 1 = Yes $2=$ No 
Q11.E refers to I try to limit snack foods

$$
1=\text { Yes } 2=\text { No }
$$

Q11F.1 refers to food labels with nutrient information are important to me or concern me

$1=$ Yes $2=$ No

Q11F.2 refers to diet, health and nutrition is important to me or concern me

1 = Yes $2=$ No

Q11F.3 refers to nutritional value is important to me or concern me

$1=$ Yes $2=$ No

Q11F.4 refers to caloric content is important to me or concern me

1 = Yes $2=$ No

Q11F.5 refers to appearance and condition are important or concern me

$1=$ Yes 2 = No

Q11F.10 refers to vitamin and mineral content are important to me or concern me

1 = Yes 2 = No

Q11.G refers my consumption of food is related to my stress situation

$1=$ Yes 2 = No 
Q1

28

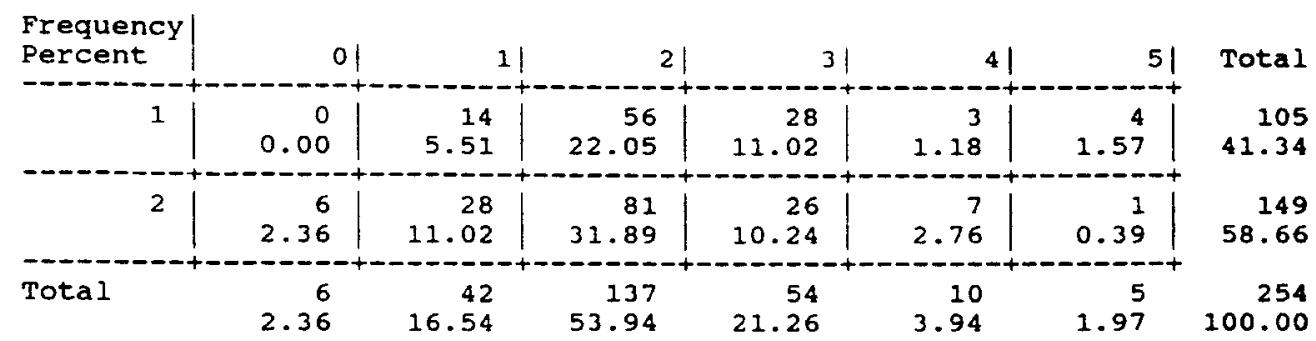

Frequency Missing $=3$

STATISTICS FOR TABLE OF Q1 BY Q8

\begin{tabular}{lccr} 
Statistic & DF & Value & Prob \\
\hline Chi-Square & 5 & 11.424 & 0.044 \\
Likelihood Ratio Chi-Square & 5 & 13.649 & 0.018 \\
Mantel-Haenszel Chi-Square & 1 & 6.307 & 0.012 \\
Phi Coefficient & & 0.212 & \\
Contingency Coefficient & & 0.207 & \\
Cramer's v & & 0.212 &
\end{tabular}

Effective Sample Size $=254$

Frequency Missing $=3$

WARNING: $42 \%$ of the cells have expected counts less than 5. Chi-Square may not be a valid test.

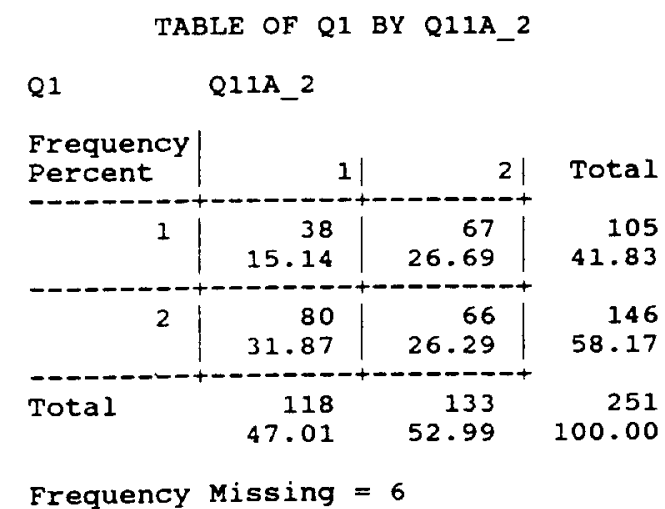

Frequency Missing $=6$

STATISTICS FOR TABLE OF Q1 BY Q11A_2

\begin{tabular}{|c|c|c|c|}
\hline statistic & $D F$ & Value & Prob \\
\hline $\begin{array}{l}\text { Chi-square } \\
\text { Likelihood Ratio Chi-square } \\
\text { Continuity Adj. Chi-Square } \\
\text { Mantel-Haenszel Chi-Square } \\
\text { Fisher's Exact Test (Left) } \\
\text { (Right) } \\
\text { (2-Tail) }\end{array}$ & $\begin{array}{l}1 \\
1 \\
1 \\
1\end{array}$ & $\begin{array}{l}8.486 \\
8.562 \\
7.755 \\
8.452\end{array}$ & $\begin{array}{r}0.004 \\
0.003 \\
0.005 \\
0.004 \\
2.60 E-03 \\
0.999 \\
4.71 E-03\end{array}$ \\
\hline $\begin{array}{l}\text { Phi coefficient } \\
\text { Contingency coefficient } \\
\text { Cramer's } v\end{array}$ & & $\begin{array}{r}-0.184 \\
0.181 \\
-0.184\end{array}$ & \\
\hline $\begin{array}{l}\text { Effective Sample Size }=251 \\
\text { Frequency Missing }=6\end{array}$ & & & \\
\hline
\end{tabular}


TABLE OF Q1 BY Q11A_4

Q1

Q11A_4

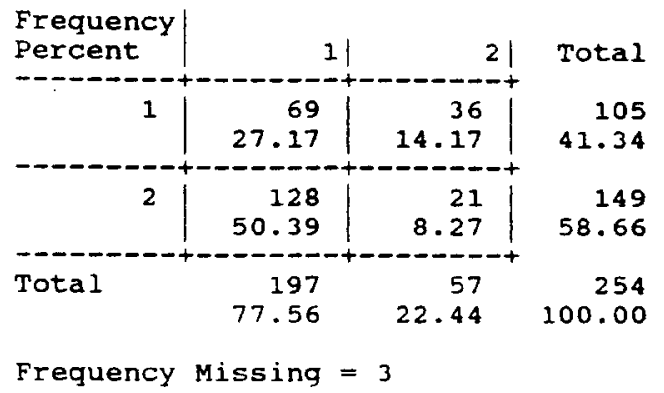

STATISTICS FOR TABLE OF Q1 BY Q11A_4

\begin{tabular}{lcrr} 
Statistic & DF & Value & Prob \\
\hline Chi-Square & 1 & 14.428 & 0.000 \\
Likelihood Ratio Chi-Square & 1 & 14.278 & 0.000 \\
Continuity Adj. Chi-Square & $I$ & 13.292 & 0.000 \\
Mantel-Haensel Chi-Square & 1 & 14.372 & 0.000 \\
Fisher's Exact Test (Left) & & & $1.43 \mathrm{E}-04$ \\
& (Right) & & 1.000 \\
(2-Tail) & & $2.14 \mathrm{E}-04$ \\
Phi Coefficient & -0.238 & \\
Contingency Coefficient & 0.232 & \\
Cramer's V & -0.238 &
\end{tabular}

Effective Sample Size $=254$

Frequency Missing $=3$

TABLE OF Q1 BY Q11B

Q1

Q11B

\begin{tabular}{|c|c|c|c|}
\hline $\begin{array}{l}\text { Frequency } \\
\text { Percent }\end{array}$ & $1 \mid$ & $2 !$ & Total \\
\hline 1 & $\begin{array}{r}59 \\
22.96\end{array}$ & $\begin{array}{r}47 \\
18.29\end{array}$ & $\begin{array}{r}106 \\
41.25\end{array}$ \\
\hline 2 & $\begin{array}{r}105 \\
40.86\end{array}$ & $\begin{array}{r}46 \\
17.90\end{array}$ & $\begin{array}{r}151 \\
58.75\end{array}$ \\
\hline Total & $\begin{array}{r}164 \\
63.81\end{array}$ & $\begin{array}{r}93 \\
36.19\end{array}$ & $\begin{array}{r}257 \\
100.00\end{array}$ \\
\hline
\end{tabular}

STATISTICS FOR TABLE OF QI BY Q11B

\begin{tabular}{lccr} 
Statistic & DF & Value & Prob \\
\hline Chi-Square & 1 & 5.193 & 0.023 \\
Likelihood Ratio Chi-Square & 1 & 5.168 & 0.023 \\
Continuity Adj. Chi-Square & 1 & 4.610 & 0.032 \\
Mantel-Haenszi Chi-Square & 1 & 5.173 & 0.023 \\
Fisher's Exact Test (Left) & & & $1.61 \mathrm{E}-02$ \\
& $($ Right) & & 0.992 \\
& & & $2.54 \mathrm{E}-02$ \\
Phi Coefficient $\quad$ (2-Tail) & -0.142 & \\
Contingency Coefficient & 0.141 & \\
Cramer's V & -0.142 &
\end{tabular}

Sample Size $=257$ 
TABLE OF Q1 BY Q11C

Q1

Q11C

\begin{tabular}{|c|c|c|c|}
\hline $\begin{array}{l}\text { Frequency } \\
\text { Percent }\end{array}$ & & 21 & Total \\
\hline 1 & $\begin{array}{r}72 \\
28.02\end{array}$ & $\begin{array}{r}34 \\
13.23\end{array}$ & $\begin{array}{r}106 \\
41.25\end{array}$ \\
\hline 2 & $\begin{array}{r}122 \\
47.47\end{array}$ & $\begin{array}{r}29 \\
11.28\end{array}$ & $\begin{array}{r}151 \\
58.75\end{array}$ \\
\hline Total & $\begin{array}{r}194 \\
75.49\end{array}$ & $\begin{array}{r}63 \\
24.51\end{array}$ & $\begin{array}{r}257 \\
100.00\end{array}$ \\
\hline
\end{tabular}

STATISTICS FOR TABLE OF QI BY QIIC

\begin{tabular}{lcrr} 
Statistic & DF & Value & Prob \\
\hline Chi-Square & 1 & 5.575 & 0.018 \\
Likelihood Ratio Chi-Square & 1 & 5.510 & 0.019 \\
Continuity Adj. Chi-Square & 1 & 4.901 & 0.027 \\
Mantel-Haenszel Chi-Square & 1 & 5.553 & 0.018 \\
Fisher's Exact Test (Left) & & & $1.38 E-02$ \\
& (Right) & & 0.994 \\
(2-Tail) & & $2.66 \mathrm{E}-02$ \\
Phi Coefficient $\quad$ & -0.147 & \\
Contingency Coefficient & 0.146 & \\
Cramer's V & -0.147 &
\end{tabular}

Sample size $=257$

TABLE OF Q1 BY Q11D

Q1

Q11D

\begin{tabular}{|c|c|c|c|}
\hline $\begin{array}{l}\text { Frequency } \\
\text { Percent }\end{array}$ & 1 & 2 & Total \\
\hline 1 & $\begin{array}{r}43 \\
16.80\end{array}$ & $\begin{array}{r}63 \\
24.61\end{array}$ & $\begin{array}{r}106 \\
41.41\end{array}$ \\
\hline 2 & $\begin{array}{r}82 \\
32.03\end{array}$ & $\begin{array}{r}68 \\
26.56\end{array}$ & $\begin{array}{r}150 \\
58.59\end{array}$ \\
\hline Total & $\begin{array}{r}125 \\
48.83\end{array}$ & $\begin{array}{r}131 \\
51.17\end{array}$ & $\begin{array}{r}256 \\
100.00\end{array}$ \\
\hline
\end{tabular}

Frequency Missing $=1$

STATISTICS FOR TABLE OF QI BY QIID

\begin{tabular}{lcrr} 
Statistic & DF & Value & Prob \\
\hline Chi-Square & 1 & 4.942 & 0.026 \\
Likelihood Ratio Chi-Square & 1 & 4.964 & 0.026 \\
Continuity Adj. Chi-Square & 1 & 4.394 & 0.036 \\
Mantel-Haenszel Chi-Square & 1 & 4.923 & 0.027 \\
Fisher's Exact Test (Left) & & & $1.79 E-02$ \\
& (Right) & & 0.991 \\
(2-Tail) & -0.139 & $3.10 E-02$ \\
Phi Coefficient & 0.138 & \\
Contingency Coefficient & & -0.139 & \\
Cramer's V & &
\end{tabular}

Effective Sample Size $=256$

Frequency Missing $=1$ 
TABLE OF Q1 BY Q11E

Q1

Q11E

\begin{tabular}{l|r|r} 
Frequency & & \\
Percent
\end{tabular}

Frequency Missing $=2$

STATISTICS FOR TABLE OF Q1 BY Q11E

\begin{tabular}{|c|c|c|c|}
\hline Statistic & DF & Value & Prob \\
\hline Chi-Square & 1 & 12.684 & 0.000 \\
\hline Likelihood Ratio Chi-square & 1 & 12.624 & 0.000 \\
\hline continuity Adj. Chi-square & 1 & 11.744 & 0.001 \\
\hline $\begin{aligned} \text { Mantel-Haenszel Chi-square } \\
\text { Fisher's Exact Test (Left) } \\
\text { (Right) } \\
\text { (2-Tail) }\end{aligned}$ & 1 & 12.634 & $\begin{array}{r}0.000 \\
3.14 E-04 \\
1.000 \\
4.64 E-04\end{array}$ \\
\hline $\begin{array}{l}\text { Phi coefficient } \\
\text { Contingency coefficient } \\
\text { Cramer's V }\end{array}$ & & $\begin{array}{r}-0.223 \\
0.218 \\
-0.223\end{array}$ & \\
\hline $\begin{array}{l}\text { Effective Sample Size }=255 \\
\text { Frequency Missing }=2\end{array}$ & & & \\
\hline
\end{tabular}

TABLE OF Q1 BY Q11F_1

Q1

Q11F_1

\begin{tabular}{|c|c|c|c|}
\hline $\begin{array}{l}\text { Frequency } \\
\text { Percent }\end{array}$ & 1 & 21 & Total \\
\hline 1 & $\begin{array}{r}47 \\
18.43\end{array}$ & $\begin{array}{r}59 \\
23.14\end{array}$ & $\begin{array}{r}106 \\
41.57\end{array}$ \\
\hline 2 & $\begin{array}{r}120 \\
47.06\end{array}$ & $\begin{array}{r}29 \\
11.37\end{array}$ & $\begin{array}{r}149 \\
58.43\end{array}$ \\
\hline Total & $\begin{array}{r}167 \\
65.49\end{array}$ & $\begin{array}{r}88 \\
34.51\end{array}$ & $\begin{array}{r}255 \\
100.00\end{array}$ \\
\hline
\end{tabular}

Frequency Missing $=2$

STATISTICS FOR TABLE OF Q1 BY Q11F_1

\begin{tabular}{lcrr} 
Statistic & DF & Value & Prob \\
\hline Chi-Square & 1 & 35.908 & 0.000 \\
Likelihood Ratio Chi-Square & 1 & 36.163 & 0.000 \\
Continuity Adj. Chi-Square & 1 & 34.324 & 0.000 \\
Mantel-Haenszel Chi-Square & 1 & 35.767 & 0.000 \\
Fisher's Exact Test (Left) & & & $2.10 \mathrm{E}-09$ \\
& (Right) & & 1.000 \\
(2-Tail) & & \\
Phi Coefficient & & 0.375 & \\
Contingency Coefficient & & 0.351 & \\
Cramer's V & -0.375 &
\end{tabular}

Effective Sample Size $=255$

Frequency Missing $=2$ 
TABLE OF Q1 BY Q11F_2

Q1

Q11F_2

\begin{tabular}{|c|c|c|c|}
\hline $\begin{array}{l}\text { Frequency } \\
\text { Percent }\end{array}$ & & 2 & Total \\
\hline 1 & $\begin{array}{r}67 \\
26.27\end{array}$ & $\begin{array}{r}39 \\
15.29\end{array}$ & $\begin{array}{r}106 \\
41.57\end{array}$ \\
\hline 2 & $\begin{array}{r}133 \\
52.16\end{array}$ & $\begin{array}{r}16 \\
6.27\end{array}$ & $\begin{array}{r}149 \\
58.43\end{array}$ \\
\hline Total & $\begin{array}{r}200 \\
78.43\end{array}$ & $\begin{array}{r}55 \\
21.57\end{array}$ & $\begin{array}{r}255 \\
100.00\end{array}$ \\
\hline
\end{tabular}

Frequency Missing $=2$

STATISTICS FOR TABLE OF Q1 BY Q11F_2

\begin{tabular}{lrrr} 
Statistic & DF & Value & Prob \\
\hline Chi-Square & 1 & 24.854 & 0.000 \\
Likelihood Ratio Chi-Square & $I$ & 24.828 & 0.000 \\
Continuity Adj. Chi-Square & 1 & 23.338 & 0.000 \\
Mantel-Haenszel Chi-Square & 1 & 24.756 & 0.000 \\
Fisher's Exact Test (Left) & & & $7.00 E-07$ \\
(Right) & & 1.000 \\
Phi Coefficient & & \\
Contingency Coefficient & -0.312 & \\
Cramer's V & 0.298 &
\end{tabular}

Effective Sample Size $=255$

Frequency Missing $=2$

TABLE OF Q1 BY Q11F 3

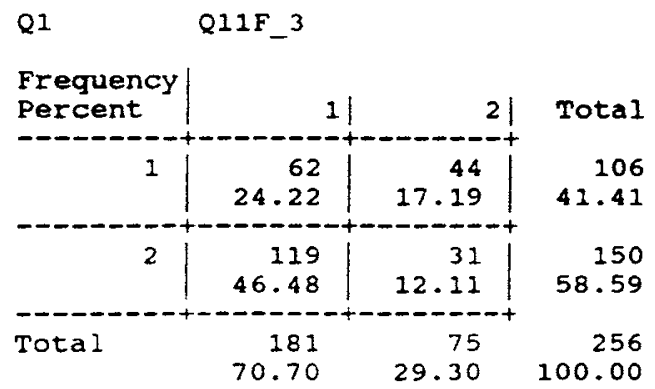

Frequency Missing $=2$

STATISTICS FOR TABLE OF Q1 BY Q11F_3

\begin{tabular}{|c|c|c|c|}
\hline statistic & DF & Value & Prob \\
\hline Chi-Square & 1 & 13.026 & 0.000 \\
\hline Likelihood Ratio Chi-square & I & 12.924 & 0.000 \\
\hline Continuity Adj. chi-square & 1 & 12.039 & 0.001 \\
\hline Mantel-Haenszel Chi-Square & 1 & 12.975 & 0.000 \\
\hline $\begin{aligned} \text { Fisher's Exact Test } & \begin{array}{l}\text { (Left) } \\
\text { (Right) } \\
\text { (2-Tail) }\end{array}\end{aligned}$ & & & $\begin{array}{r}2.73 E-04 \\
1.000 \\
4.53 E-04\end{array}$ \\
\hline $\begin{array}{l}\text { Phi coefficient } \\
\text { contingency coefficient } \\
\text { Cramer's V }\end{array}$ & & $\begin{array}{r}-0.226 \\
0.220 \\
-0.226\end{array}$ & \\
\hline
\end{tabular}

Effective Sample Size $=256$

Frequency Missing $=1$ 
TABLE OF Q1 BY Q11F_4

Q1

Q11F_4

\begin{tabular}{|c|c|c|c|}
\hline $\begin{array}{l}\text { Frequency } \\
\text { Percent }\end{array}$ & & & t \\
\hline 1 & $\begin{array}{r}36 \\
14.17\end{array}$ & $\begin{array}{r}69 \\
27.17\end{array}$ & 41.3 \\
\hline 2 & $\begin{array}{r}92 \\
36.22\end{array}$ & $\begin{array}{r}57 \\
22.44\end{array}$ & $\begin{array}{r}149 \\
58.6\end{array}$ \\
\hline Total & $\begin{array}{r}128 \\
50.39\end{array}$ & $\begin{array}{r}126 \\
49.61\end{array}$ & 100. \\
\hline
\end{tabular}

Frequency Missing $=3$

STATISTICS FOR TABLE OF Q1 BY Q11F_4

\begin{tabular}{lcrr} 
Statistic & DF & Value & Prob \\
\hline Chi-Square & 1 & 18.578 & 0.000 \\
Likelihood Ratio Chi-Square & 1 & 18.832 & 0.000 \\
Continuity Adj. Chi-Square & 1 & 17.496 & 0.000 \\
Mantel-Haenszel Chi-Square & 1 & 18.505 & 0.000 \\
Fisher's Exact Test (Left) & & & $1.29 \mathrm{E}-05$ \\
& (Right) & & 1.000 \\
Phi Coefficient & (2-Tail) & -0.270 & $2.33 \mathrm{E}-05$ \\
Contingency Coefficient & & 0.261 & \\
Cramer's V & -0.270 &
\end{tabular}

Effective Sample Size $=254$

Frequency Missing $=3$

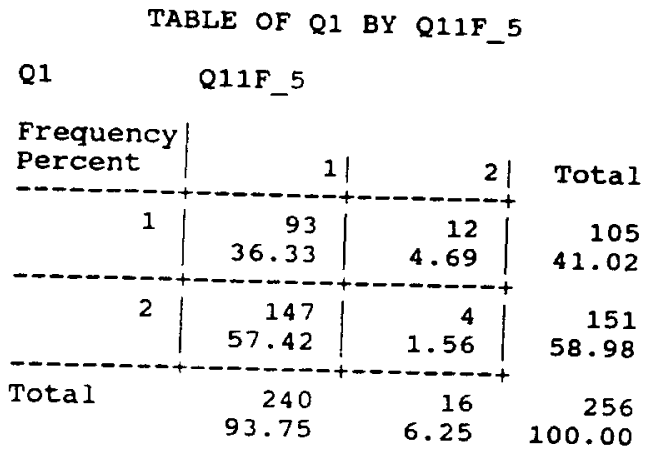

Frequency Missing $=1$

STATISTICS FOR TABLE OF Q1 BY Q11F_5

\begin{tabular}{lrrr} 
Statistic & DF & Value & Prob \\
\hline Chi-Square & 1 & 8.147 & 0.004 \\
Likelihood Ratio Chi-Square & 1 & 8.130 & 0.004 \\
Continuity Adj. Chi-Square & 1 & 6.718 & 0.010 \\
Mantel-Haenszel Chi-Square & 1 & 8.116 & 0.004 \\
Fisher's Exact Test (Left) & & & $4.92 \mathrm{E}-03$ \\
(Right) & & 0.999 \\
(2-Tail) & & $6.95 \mathrm{E}-03$ \\
Phi Coefficient & -0.178 & \\
Contingency Coefficient & 0.176 & \\
Cramer's V & -0.178 & \\
Effective Sample Size 256 & & \\
Frequency Missing 1 &
\end{tabular}


TABLE OF Q1 BY Q11G

Q1

Q11G

\begin{tabular}{|c|c|c|c|}
\hline $\begin{array}{l}\text { Frequency } \\
\text { Percent }\end{array}$ & 1 & 2 & Total \\
\hline 1 & $\begin{array}{r}38 \\
15.14\end{array}$ & $\begin{array}{r}64 \\
25.50\end{array}$ & $\begin{array}{r}102 \\
40.64\end{array}$ \\
\hline 2 & $\begin{array}{r}92 \\
36.65\end{array}$ & $\begin{array}{r}57 \\
22.71\end{array}$ & $\begin{array}{r}149 \\
59.36\end{array}$ \\
\hline tal & $\begin{array}{r}130 \\
51.79\end{array}$ & $\begin{array}{r}121 \\
48.21\end{array}$ & $\begin{array}{r}251 \\
100.00\end{array}$ \\
\hline
\end{tabular}

Frequency Missing $=6$

STATISTICS FOR TABLE OF Q1 BY Q11G

\begin{tabular}{lcrr} 
Statistic & DF & Value & Prob \\
\hline Chi-Square & 1 & 14.545 & 0.000 \\
Likelihood Ratio Chi-Square & 1 & 14.677 & 0.000 \\
Continuity Adj. Chi-Square & 1 & 13.581 & 0.000 \\
Mantel-Haenszi Chi-Square & 1 & 14.487 & 0.000 \\
Fisher's Exact Test (Left) & & & $1.08 \mathrm{E}-04$ \\
$\quad$ (Right) & & 1.000 \\
(2-Tail) & & $1.81 \mathrm{E}-04$ \\
Phi Coefficient $\quad 0.241$ & \\
Contingency Coefficient & 0.234 & \\
Cramer's V & -0.241 & \\
Effective Sample Size $=251$ & & \\
Frequency Missing $=6$ & &
\end{tabular}


TABLE OF Q4 BY Q11F_10

Q4 Q11F_10

\begin{tabular}{|c|c|c|c|}
\hline $\begin{array}{l}\text { Frequency } \\
\text { Percent }\end{array}$ & $I$ & 2 & Total \\
\hline 1 & $\begin{array}{r}48 \\
18.90\end{array}$ & $\begin{array}{r}55 \\
21.65\end{array}$ & $\begin{array}{r}103 \\
40.55\end{array}$ \\
\hline 2 & $\begin{array}{r}27 \\
10.63\end{array}$ & $\begin{array}{r}37 \\
14.57\end{array}$ & $\begin{array}{r}64 \\
25.20\end{array}$ \\
\hline 3 & $\begin{array}{r}25 \\
9.84\end{array}$ & $\begin{array}{r}14 \\
5.51\end{array}$ & $\begin{array}{r}39 \\
15.35\end{array}$ \\
\hline 4 & $\begin{array}{r}24 \\
9.45\end{array}$ & $\begin{array}{r}14 \\
5.51\end{array}$ & $\begin{array}{r}38 \\
14.96\end{array}$ \\
\hline 5 & $\begin{array}{r}8 \\
3.15\end{array}$ & $\begin{array}{r}0 \\
0.00\end{array}$ & $\begin{array}{r}8 \\
3.15\end{array}$ \\
\hline 6 & $\begin{array}{r}0 \\
0.00\end{array}$ & $\begin{array}{r}2 \\
0.79\end{array}$ & $\begin{array}{r}2 \\
0.79\end{array}$ \\
\hline Total & $\begin{array}{r}132 \\
51.97\end{array}$ & $\begin{array}{r}122 \\
48.03\end{array}$ & $\begin{array}{r}254 \\
100.00\end{array}$ \\
\hline
\end{tabular}

Frequency Missing $=3$

STATISTICS FOR TABLE OF Q4 BY Q1IF_ 10

\begin{tabular}{lccc} 
Statistic & DF & Value & Prob \\
\hline Chi-Square & 5 & 17.406 & 0.004 \\
Likelihood Ratio Chi-Square & 5 & 21.322 & 0.001 \\
Mantel-Haenszel Chi-Square & 1 & 6.981 & 0.008 \\
Phi Coefficient & & 0.262 & \\
Contingency Coefficient & 0.253 & \\
Cramer's V & 0.262 & \\
Effective Sample Size = 254 & \\
Frequency Missing $=3$ & \\
wARNING: 33\% of the cells have expected counts less \\
than 5. Chi-Square may not be a valid test.
\end{tabular}


TABLE OF Q5 BY Q11F_2

\begin{tabular}{|c|c|c|c|}
\hline Q5 & $1 F_{-} 2$ & & \\
\hline $\begin{array}{l}\text { Frequency } \\
\text { Percent }\end{array}$ & 1 & $2 !$ & Total \\
\hline 1 & $\begin{array}{r}71 \\
28.17\end{array}$ & $\begin{array}{r}11 \\
4.37\end{array}$ & $\begin{array}{r}82 \\
32.54\end{array}$ \\
\hline 2 & $\begin{array}{r}34 \\
13.49\end{array}$ & $\begin{array}{r}18 \\
7.14\end{array}$ & $\begin{array}{r}52 \\
20.63\end{array}$ \\
\hline 3 & $\begin{array}{r}20 \\
7.94\end{array}$ & $\begin{array}{r}1 \\
0.40^{1}\end{array}$ & $\begin{array}{r}21 \\
8.33\end{array}$ \\
\hline 4 & $\begin{array}{r}16 \\
6.35\end{array}$ & $\begin{array}{r}5 \\
1.98\end{array}$ & $\begin{array}{r}21 \\
8.33\end{array}$ \\
\hline 5 & $\begin{array}{r}18 \\
7.14\end{array}$ & $\begin{array}{r}3 \\
1.19\end{array}$ & $\begin{array}{r}21 \\
8.33\end{array}$ \\
\hline 7 & $\begin{array}{r}34 \\
13.49\end{array}$ & $\begin{array}{r}16 \\
6.35\end{array}$ & $\begin{array}{r}50 \\
19.84\end{array}$ \\
\hline 8 & $\begin{array}{r}3 \\
1.19\end{array}$ & $\begin{array}{r}0 \\
0.00\end{array}$ & $\begin{array}{r}3 \\
1.19\end{array}$ \\
\hline 9 & $\begin{array}{r}2 \\
0.79\end{array}$ & $\begin{array}{r}0 \\
0.00\end{array}$ & $\begin{array}{r}2 \\
0.79\end{array}$ \\
\hline Dtal & $\begin{array}{r}198 \\
78.57\end{array}$ & $\begin{array}{r}54 \\
21.43\end{array}$ & $\begin{array}{r}252 \\
100.00\end{array}$ \\
\hline
\end{tabular}

Frequency Missing $=5$

STATISTICS FOR TABLE OF Q5 BY Q11F_2

\begin{tabular}{lcrr} 
Statistic & DF & Value & Prob \\
\hline Chi-Square & 7 & 17.353 & 0.015 \\
Likelihood Ratio Chi-Square & 7 & 19.132 & 0.008 \\
Mantel-Haensel Chi-Square & 1 & 1.537 & 0.215 \\
Phi Coeficient & & 0.262 & \\
Contingency Coefficient & 0.254 & \\
Cramer's V & 0.262 & \\
Effective Sample Size $=252$ & & \\
Frequency Missing $=5$ & \\
WARNING: 44t of the Cells have expected counts less \\
$\quad$ than 5. Chi-Square may not be a valid test.
\end{tabular}




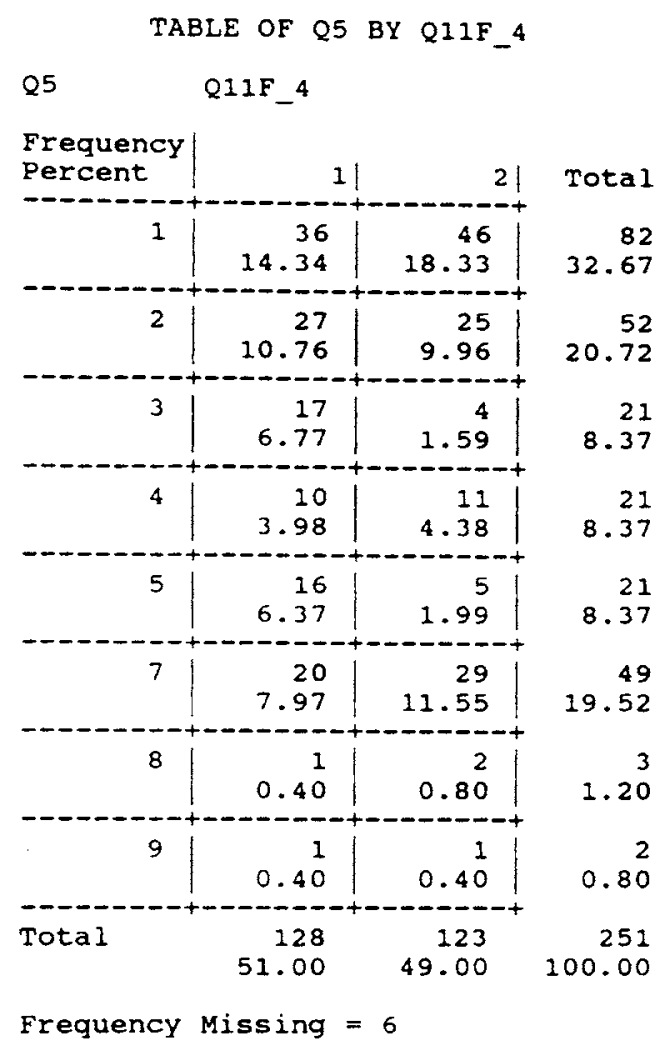

STATISTICS FOR TABLE OF Q5 BY Q11G

\begin{tabular}{lccr} 
Statistic & DF & Value & Prob \\
\hline Chi-Square & 7 & 16.030 & 0.025 \\
Likelihood Ratio Chi-Square & 7 & 17.387 & 0.015 \\
Mantel-Haensel Chi-Square & 1 & 0.637 & 0.425 \\
Phi Coefficient & & 0.254 & \\
Contingency Coefficient & 0.246 & \\
Cramer's V & 0.254 & \\
Effective Sample Size $=248$ & \\
Frequency Missing $=9$ & \\
WARNING: 25\% of the cells have expected courts less &
\end{tabular}


APPENDIX E

INSTITUTIONAL REVIEW BOARD

APPROVAL FORM 


\section{ORLAHOMA STATE ONIVERSITY INSTITUTIONAL REVIEW BOARD HUMAN SUBJECTS REVIEW}

Date: $02-24-94$

IRB\# : $\quad H E-94-028$

Proposal TitIe: MEAT CONSUMPTION PATTERNS OF COLLEGE STUDENTS

Principal Investigator(s): Lea Ebro, Kellie Bryant

Reviewed and Processed as: Exempt

Approval Status Recommended by Reviewer(s): Approved

APPROVAL STATUS SUBJECT TO REVIEW BY FULL INSTITUTIONAL REVIEW BOARD AT NEXT MEETING.

APPROVAL STATUS PERIOD VAIID FOR ONE CALENDAR YEAR AFTER WHICH A CONTINUATION OR RENEWAL REQUEST IS REQUIRED TO BE SUBMITTED FOR BOARD APPROVAL. ANY MODIFICATIONS TO APPROVED PROJECT MUST ALSO BE SUBMITTED FOR APPROVAL.

Comments, Modifications/Conditions for Approval or Reasons for Deferral or Disapproval are as follows:

Please add a phone number for one of the PI's to the cover letter to allow for questions concerning the study.

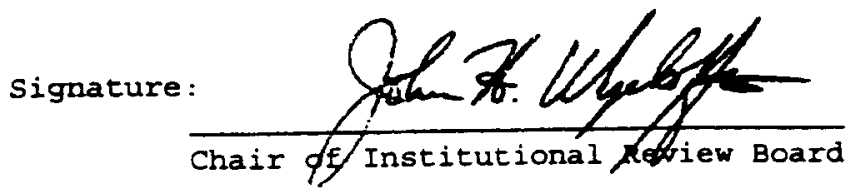

Date: February 28, 1994 


\author{
VITA ${ }^{2}$ \\ Kellie Renae Bryant \\ Candidate for the Degree of \\ Master of Science
}

Thesis: NUTRITION AWARENESS AND MEAT CONSUMPTION OF COLLEGE STUDENTS

Major Field: Nutritional Sciences

Biographical:

Personal Data: Born in Pawnee, Oklahoma, January 10, 1970, the daughter of Johnny $L$. and Janice $M$. (Kelley) Bryant.

Education: Graduated from Pawnee High School, Pawnee, Oklahoma, in May, 1988; received Bachelor of Science Degree in Nutritional Sciences from Oklahoma state University, Stillwater, Oklahoma in July, 1992; completed Approved Pre-Professional Practice Program at oklahoma State University, May, 1993; passed registration exam to meet requirements for American Dietetic Association membership in October, 1993; completed requirements for the Master of Science Degree at Oklahoma State University in July, 1994.

Professional Experience: Consultant Dietitian Wheatheart Nutrition Project, Tonkawa, Oklahoma, October 1993 to present; Graduate Research Assistant, School of Hotel and Restaurant Administration, Oklahoma State University, January 1994 to present.

Professional Organizations: American Dietetic Association, Oklahoma Dietetic Association, Institute of Food Technologists, and Kappa Omicron $\mathrm{Nu}$. 